\title{
Prolingua se bydrae tot terminologieontwikkeling in Afrikaans
}

\author{
Mariëtta Alberts, Navorsingseenheid: Taal en Literatuur \\ in die SA Konteks, Noordwes-Universiteit, Potchefstroomkampus, \\ Potchefstroom, Suid-Afrika (albertsmarietta@gmail.com)
}

\begin{abstract}
Prolingua's Contribution to Terminology Development in Afrikaans. The research problem addressed in this article deals with the isolated development of Afrikaans terminology in a multilingual dispensation. The research problem manifests itself in three ways: the need for such terminology; the sustainability thereof; and whether a single institution, such as Prolingua, could maintain such development. Prolingua, an association for English and Afrikaans language practitioners, was founded in 1950. At the time it was known as the Transvaal Association of Municipal Translators. As the name indicated, the members were mainly municipal officials. Municipal services included several services that, at the time needed bilingual terms for various areas in the workplace. The country's bilingual language policy then required terms to be translated and created for all municipal departments - suddenly there was a need for Afrikaans terms. The aim of the newly established association was, among other things, to translate, create and standardise terminology and to discuss problems with translation. Later more attention was given to terminology-related problems and the association became more inclusive and inviting for language practitioners from other institutions to join its ranks. This article deals with the need for Afrikaans terminology and gives information on the history of Prolingua and its contribution to terminology development in Afrikaans, i.e. the Prolingua term list and other products and services. The contributions made by external collaborators regarding terminology development also receive attention. Prolingua's cooperation with other institutions is discussed. The article concludes with recommendations for a way forward.
\end{abstract}

Keywords: CLASSIC ORIGIN, COLLABORATOR, COOPERATION, DATABASE, DIGITISATION, DIGITALISATION, HARMONISATION, LANGUAGE POLICY, LANGUAGE PRACTITIONER, NEOLOGISM, ONLINE TERMINOLOGY PRODUCTS, STANDARDISATION, TECHNICAL DICTIONARY, TERM CREATION, TERM LIST, TERMINOLOGY DEVELOPMENT, TERMINOLOGY, TERMINOLOGY MANAGEMENT SYSTEM

Opsomming: Die navorsingsprobleem wat in hierdie artikel bespreek word, handel oor die geïsoleerde ontwikkeling van Afrikaanse terminologie in 'n meertalige bestel. Die probleem manifesteer homself op drieërlei wyse: die behoefte aan sodanige terminologie; die volhoubaarheid daarvan; en of ' $n$ enkele instansie, soos Prolingua, daartoe in staat is om sodanige ontwikkeling te handhaaf. Prolingua, 'n vakvereniging vir Engelse en Afrikaanse taalpraktisyns, is in 1950 gestig. Dit het toe bekend gestaan as die Transvaalse Vereniging van Munisipale Vertalers. Soos die naam aandui, was die lede hoofsaaklik munisipale beamptes. Munisipale dienste het verskeie dienste 
ingesluit wat gedurende hierdie tydperk tweetalige terme vir verskeie gebiede in die werksplek benodig het. Die land se tweetalige beleid het vereis dat terme vertaal en geskep moes word vir alle munisipale departemente - skielik was daar 'n behoefte aan Afrikaanse terme. Die doel van die nuutgestigte vereniging was om onder andere te vertaal, te skep en terminologie te standaardiseer en probleme wat met vertaling ondervind is, te bespreek. Later is meer klem op terminologieverwante probleme gelê en die vereniging het meer inklusief en aanloklik vir taalpraktisyns verbonde aan ander instansies geraak om by sy geledere aan te sluit. Hierdie artikel gee aandag aan die behoefte aan Afrikaanse terminologie en die ontstaan van Prolingua en sy bydrae tot terminologieontwikkeling in Afrikaans, soos die Prolingua-termlys en ander produkte en dienste. Die bydraes deur eksterne medewerkers ten opsigte van terminologieontwikkeling kry ook aandag. Prolingua se samewerking met ander instansies word bespreek. Die artikel word afgesluit met aanbevelings oor die pad vorentoe.

Sleutelwoorde: AANLYN TERMINOLOGIEPRODUKTE, DATABASIS, DIGITISERING, DIGITALISERING, HARMONISERING, KLASSIEKE OORSPRONG, MEDEWERKER, NEOLOGISME, SAMEWERKING, STANDAARDISERING, TAALBELEID, TAALPRAKTISYN, TERMINOLOGIE，TERMINOLOGIEBESTUURSTELSEL，TERMINOLOGIEONTWIKKELING，TERMLYS, TERMSKEPPING, VAKWOORDEBOEK

\section{Inleiding}

Vaktaal is zowel een zegen als een vloek. Het is een zegen om met nauwkeurig gedefinieerde termen snel en eenduidig informatie uit te wisselen over handelingen en objecten binnen een vakgebied. Maar buiten de kring van vakgenoten wordt vakjargon niet begrepen en evenmin gewaardeerd.

(Burger en De Jong 1997: 169)

Die navorsingsproblematiek wat in hierdie ondersoek onder die loep kom, handel oor die geïsoleerde ontwikkeling van Afrikaanse terminologie in ' $n$ meertalige bestel. Die probleem manifesteer homself op drieërlei wyse:

- die behoefte aan Afrikaanse terminologie wat nie deel is van meertalige termlyste, vakwoordeboeke of termdatabasisse nie;

- die volhoubaarheid van die geïsoleerde ontwikkeling van Afrikaanse terminologie; en

- die moontlikheid dat ' $n$ enkele instansie, soos Prolingua, daartoe in staat is om sodanige terminologieontwikkeling te handhaaf en selfs uit te bou.

Terminologieontwikkeling vind nie in isolasie plaas nie en geskied binne die konteks van die taalbeleid van 'n regering. Suid-Afrika beskik oor voortreflike wetgewing wat die talebestel behoort te beskerm en taalontwikkeling te fasiliteer. Die Grondwet van die Republiek van Suid-Afrika (1996) maak voorsiening vir die ontwikkeling van al elf amptelike tale en die Nasionale Taalbeleidsraamwerk van Maart 2003 gee uiting aan die grondwetlike vereistes vir taalgebruik en -ontwikkeling. Verder gee die wetgewing oor die Gebruik van 
die Amptelike Tale (2012) en die voorgestelde regulasies (2013) riglyne oor taalgebruik op nasionale, provinsiale en plaaslike regeringsvlak. Die Suid-Afrikaanse Taalpraktisynsraad (2014) maak onder andere voorsiening daarvoor dat taalpraktisyns oor die nodige vaardighede beskik om in die taalpraktyk werksaam te wees. Wetgewing vereis dus by implikasie dat daar tans aan meertalige terminologieontwikkeling aandag gegee moet word (Alberts 2017: 150-163).

Terminologie fasiliteer taalontwikkeling, die skep van kennis en die verspreiding van inligting, want terminologie is die medium waardeur inligting versprei en kennis oorgedra word. Wanneer dit by vaktaal kom, moet die gestandaardiseerde terminologieë van verskeie vakgebiede, domeine en werkverwante belangegebiede dus in plek wees vir suksesvolle konseptualisering, om inligting te ontsluit en kennis te orden, vir inligtingoordrag en om kennisverwerwing te fasiliteer. Daar is derhalwe ' $n$ voortdurende behoefte aan terminologie (Alberts 1998; Alberts 2003: 128).

As gevolg van die verskeidenheid beroepe wat deur die lede van 'n gemeenskap beoefen word, ontstaan daar ' $n$ aantal beroepstale of tegnolekte wat ook vaktaal genoem word. Elke beroep, wetenskaplike of tegnologiese rigting ontwikkel sy eie vaktaal en vir elke nuwe vakdissipline wat ontwikkel, ontstaan daar 'n nuwe vaktaal met 'n unieke terminologie. Hierdie vaktale se terminologie word gedokumenteer en aan die gemeenskap beskikbaar gestel om sodoende by te dra tot gestandaardiseerde vakkommunikasie (vgl. Alberts 1998; Alberts 2003: 128).

Tegnologiese vooruitgang, nuwe spesialisvelde en die tempo van nuwe ontwikkelings plaas vakkundiges en taalpraktisyns midde-in die wêreldwye kennisontploffing waarbinne effektief gekommunikeer moet word (Luther 2005). Die behoefte aan ondubbelsinnige kommunikasie in die teoretiese en toegepaste velde van menslike aktiwiteit neem gevolglik steeds toe (Mollema en Alberts 2011; Alberts en Mollema 2013). Hierdie wêreldwye tendens beïnvloed die werksomgewing en die manier waarop gemeenskappe daagliks interaktief verkeer en daar moet gevolglik voortdurend kreatief gedink word oor termskepping (Prolingua 2015: 1). 'n Groot behoefte aan meertalige terminologieskepping ontstaan aangesien verskillende sake in die tale van die onderskeie gemeenskappe bedryf word (Mtintsilana en Morris 1988: 109). Taalpraktisyns moet as fasiliteerders dien om vakinligting in verskillende tale aan vakgemeenskappe toeganklik te maak.

Die ontwikkeling van die verskillende inheemse tale het deur verskeie fases plaasgevind. Afrikaans het van 'n ondergeskikte taal ontwikkel tot 'n hoëfunksietaal wat op enige vakgebied of terrein gebruik kan word. Waar Afrikaans tans op ' $n$ handhaaffase moes wees, is die taal egter terug na ' $n$ stryd om oorlewing. Die Afrikatale word ten spyte van hul amptelike taalstatus nie voldoende ontwikkel nie. Engels is steeds die taal van voorkeur vir baie en dit wil voorkom of al die ander amptelike tale met moeite van die hegemonie van Engels sal ontkom (Alberts 2017: 140-150). Dit is belangrik om daarop te let dat ' $n$ taal wat funksioneel is ' $n$ taal met ' $n$ toekoms is: "Hoe meer funksies ' $n$ taal 
verloor, hoe vinniger gaan die taal se gebruikswaarde agteruit; hoe kleiner krimp sy taalwêreld; en hoe makliker verskuif sy taalgemeenskap na ' $n$ ander, meer bruikbare taal" (Buys 2014: 4). Sonder (vak)taal kan daar immers nie sprake wees van behoorlike kommunikasie nie.

'n Blik op die historiese ontwikkeling van vaktaal in Suid-Afrika toon dat dit ' $n$ moeisame en langsame proses was (Alberts 2017: 163-170). As daar egter gekyk word na die hoeveelheid vakwoordeboeke en termlyste wat amptelik sedert 1950 geproduseer is, is vaktaalontwikkeling in Suid-Afrika 'n suksesverhaal (NTD 1998). 'n Oudit wat in 2015 in opdrag van die Suid-Afrikaanse Akademie vir Wetenskap en Kuns en Dagbreek Trust uitgevoer is, toon dat daar 362 vakwoordeboektitels was. Hoewel sommige vakwoordeboeke en termlyste uit druk is, blyk dit dat daar aan ' $n$ verskeidenheid dissiplines aandag gegee is, hoewel daar egter ook baie dupliserings van projekte was ten spyte van vele koördinerende liggame (Alberts 2015a; Alberts 2017: 165, 171). Daar word gesê dat spesialiskennis, afhangende van die betrokke spesialisveld, elke vyf tot vyftien jaar verdubbel (Luther 2005). Leemtes en toekomstige behoeftes kan bepaal word deur na bestaande vakwoordeboekprodukte te kyk.

Afrikaanse vaktaal is sedert die vyftigerjare aktief ontwikkel en 'n verskeidenheid vakgebiede se terminologieë is sedertdien gedokumenteer en gestandaardiseer. Die getal vakwoordeboekpublikasies met Afrikaans as een van die behandelde tale het van sowat 150 beskikbare titels in 1990 (baie van hulle toe reeds uit druk, maar destyds nog verkrygbaar) tot minder as 20 titels in 2005 gekrimp (Luther 2005).

In Suid-Afrika is die primêre terminologiedokumentering steeds in Engels en by sekondêre termskepping word die Afrikaanse termekwivalente (en definisies) gewoonlik eerste bygevoeg - bloot omdat Afrikaanse termekwivalente in baie gevalle reeds beskikbaar is. Daarna volg die Afrikatale as doeltale. Lesse wat reeds uit verskeie meertalige terminologieprojekte geleer is, is dat Afrikaanse terme en definisies dikwels meer toeganklik is vir die Afrikataalmedewerkers as die Engelse weergawes.

Die ontwikkelaars van Afrikataalterminologie behoort te leer uit die foute wat met die Afrikaanse vaktaalontwikkeling begaan is. Die Afrikaanse vakwoordeboeke en termlyste was merendeels glossariums sonder bykomende, toeligtende terminologiese inligting. Die huidige samestellers van vakwoordeboeke, termlyste en termdatabasisse is gelukkig reeds besig om die dokumenteringsproses te verbeter, want verklarings, voorbeeldsinne en ander tersaaklike inligting word tans bygevoeg. Dit is bloot makliker om die inligting verbonde aan 'n konsep behoorlik te ontsluit indien daar 'n behoorlike verklaring van die konsep is en die brontaalterm in konteks verskyn. Rekenaartoepassings vergemaklik ook verskeie (sleur)prosesse wat deel is van die terminologieontwikkelingsproses. Meertalige termlyste oor ' $n$ verskeidenheid vakterreine is deesdae ook aanlyn beskikbaar.

Prolingua se bydrae tot terminologieontwikkeling moet teen hierdie agtergrond beskou word. Maar wie of wat is Prolingua? Prolingua is 'n 'Vereniging 
vir Afrikaanse en Engelse Taalpraktisyns'. ' $n$ Mens sou met reg kon vra of daar tans in Suid-Afrika met sy meertalige taalbeleid nog plek vir en ' $n$ behoefte aan 'n vakvereniging sou kon wees wat aan slegs twee van die amptelike tale aandag gee. Die antwoord is onomwonde positief, want daar is steeds taalpraktisyns wat in die huidige meertalige bestel hul daaglikse brood in Afrikaans en Engels verdien.

Die taalpraktisyns wat daagliks met Engels en Afrikaans omgaan, kom met verskeie (gewoonlik Engelse) terme in aanraking wat nie noodwendig reeds in vakwoordeboeke gedokumenteer en gestandaardiseer is nie. Hulle moet dan uiteraard vinnig (gewoonlik Afrikaanse) termekwivalente skep. Die lede van hierdie vereniging bied die nodige ondersteuning aan mekaar en aan ander taalpraktisyns om 'n aanduiding te gee of die termekwivalente reeds in gebruik is, maar nog net nie in vakwoordeboeke opgeteken is nie, of om waar nodig nuwe terme te help skep. Dit blyk dat Afrikaanse terme, wat as deel van meertalige termlyste, vakwoordeboeke of termdatabasisse gedokumenteer word, dikwels reeds in ander vaktaalbronne bestaan en daar is dus nie sprake van nuutskeppings in Afrikaans nie.

\section{Prolingua: Agtergrond}

Op 8 Mei 1925 word Afrikaans naas Engels en Nederlands as amptelike taal van Suid-Afrika erken. Dit was 'n tyd waarin daar skielik vele uitdagings aan staatsamptenare en munisipale werkers gestel is wat skielik ook in Afrikaans moes werk en skryf. Verskeie vertaal- en terminologiekantore is by staatsdepartemente en munisipale kantore gestig (Alberts 2015a), maar die taalpraktisyns was nie opgeleide vertalers of terminoloë nie - hulle het grade in letterkunde en linguistiek gehad, maar geen formele vertaal- of terminologieopleiding nie. Niemand het in daardie stadium kennis gedra van vertaalteorieë of termskeppingspraktyke nie - vertaalwerk en termskepping het gevolglik gewoon intuïtief plaasgevind. Daar is van die taalpraktisyns verwag om hierdie praktykgerigte opleiding in die loop van hul normale werkslading te bekom. Daar was egter geen gebrek aan entoesiasme en ywer nie en dikwels was die motivering bloot om te verseker dat Afrikaans sy man teen 'n wêreldtaal soos Engels kon staan (Prolingua 2015: 1).

Een van die grootse probleme was die gebrek aan vakwoordeboeke. Die taalpraktisyns verbonde aan staatsdepartemente en munisipaliteite het gevolglik begin om hul eie termlyste vir interne gebruik saam te stel. Daar was by slegs ' $n$ paar van die taalkantore ook terminologieseksies wat tweetalige vakwoordeboeke saamgestel en gepubliseer het. Die probleem met die interne termlyste was dat daar geen koördinering van werksaamhede of terme was nie wat aanleiding gegee het tot ' $n$ proliferasie van terme wat nie gestandaardiseer was nie.

Op Saterdag 28 Oktober 1950, skaars 25 jaar na die amptelike erkenning van Afrikaans as amptelike taal van Suid-Afrika, is 'n vereniging, die Trans- 
vaalse Vereniging van Munisipale Vertalers, gestig om hoofsaaklik vertalers verbonde aan verskeie munisipaliteite met vertaalprobleme van Engels na Afrikaans te help.

Die Vereniging van Munisipale Vertalers het met ander taalkantore en staatsdepartemente soos die Terminologieseksie van die Taaldiensburo, die Buro van Standaarde, die Taaldiens van die Weermag, die Spoorwegtaalburo, die Poskantoortaaldiens en provinsiale administrasies saamgewerk. Taalpraktisyns verbonde aan hierdie en ander instellings het ook lede van die Vereniging geword. Die lede het gewoonlik op Saterdae byeengekom om terme te vertaal of te skep. Hulle het op eie koste die vergaderings bygewoon. Aangesien baie werknemers verbonde aan die munisipaliteite destyds lede was van die Vereniging is terminologievergaderings om die beurt by die Stadsraad van Pretoria en by die Stadsraad van Johannesburg gehou.

Munisipale dienste het verskeie departemente en terreine ondersteun waarvoor Afrikaanse terme voorsien moes word, byvoorbeeld kragopwekking en -verspreiding, riool, afvalwater en watersuiwering, gasfabrieke, brandweer, bus- en tremdienste, tegniese werkwinkels, markte, slagpale, afvalverwydering, vullishope, krematoriums, begraafplase, parke, padbou en -instandhouding, verkeersbeheer, opmeting, waarderings, stedelike beplanning, argitekte, regsadviseurs, rekenmeesters, begrotings, administrasie, personeelaangeleenthede, museums, kunsmuseums en biblioteke (Prolingua 2015: 2; Alberts 2015a).

Die vakvereniging se hoofdoel was om terme te voorsien, te standaardiseer en vertaalprobleme op te los. Die Vereniging het gou deur die land bekend geword en as gevolg van die belangstelling deur nasionale instansies en munisipaliteite in ander provinsies as Transvaal, is die naam verander na die Vereniging van Munisipale Vertalers en die lede is toegelaat om vergaderings in kantoortyd by te woon. 'n Verteenwoordiger van die Vereniging het ook op die Koördinerende Vaktaalraad (KOVAK) gedien (Alberts 2015a; Alberts 2017: 165-167).

Later is meer klem op terminologiewerk gelê en die Vereniging se naam is verander na die Terminologievereniging van Suid-Afrika (Termsa). Die naam is in die negentigerjare verander na Prolingua (pro: 'n voorvoegsel uit Latyn wat 'voor', 'ten gunste van', 'ondersteun' beteken; lingua: uit Latyn wat 'tong' of 'taal' beteken) (Prolingua 2015: 2; Alberts 2015a).

Prolingua is ' $n$ vakvereniging vir taalpraktisyns waar werksvergaderings maandeliks gehou word om terminologieprobleme te bespreek en nuwe terme te skep. Dit is hierdie taalpraktisyns se passie om nuwe terme te skep in 'n veranderende en opwindende globale wêreld en om meer van hul professie te wete te kom. Hoewel Prolingua tweetalig is, is daar steeds 'n groter behoefte aan die skep van Afrikaanse terme (Prolingua 2015: 2).

Daar word jaarliks tien werksvergaderings gehou wat om die beurt by die kantore van die Tshwane Munisipaliteit in Centurion en by Unisa se Floridakampus, Roodepoort gehou word. Tydens die werksvergaderings word terminologieprobleme bespreek en die Prolingua-termlys word hersien en bygewerk. Prolingua gee gereeld erkenning aan lede (en nielede) wat uitmuntende 
diens op taalgebied lewer en toekennings word dan gegee of erelidmaatskap word aan dié lede toegeken.

Hoewel daar tans akademiese kursusse is vir taalpraktisyns om hulle as vertalers, tolke, redigeerders en terminoloë te bekwaam, werk taalpraktisyns dikwels alleen en het 'n behoefte aan kontak met ander taalwerkers. Buiten die gereelde werksvergaderings is daar ook 'n aktiewe groep wat termprobleme per e-pos bespreek. Prolingua het ook 'n Yahoo-gespreksgroep (Prolingua99 @yahoo.com) waar lede mekaar met die vertaling van dringende terme help.

Gassprekers word na die maandelikse werksvergaderings genooi om aspekte van terminologie te behandel (Alberts 2012; Bosman 2015; Jonker 2013; Burger 2016; Van Nierop 2016; Russouw 2017; Van Huyssteen 2017) of verskeie ander taalverwante sake te bespreek, soos tersaaklike wetgewing (Beukes 2014; Malan 2014; Le Roux 2016), taalaspekte (Posthumus 2016; Van Rooy 2017); vertaal- en redigeerkwessies, eenvoudige en korrekte taalgebruik en kompakte skryfwyse (Cornelius 2012; Geldenhuys, Dykman en Viljoen-Smook 2012; Dykman 2015; Viljoen-Smook, Geldenhuys en Coetzee 2017), taalverwante programmatuur (Fourie 2014; Van Huyssteen 2014), forensiese linguistiek (Kotzé 2015), teksredigering (Carstens 2011, 2014; Linnegar 2013, 2014), tekstegnologie (Prinsloo 2011; Roux 2016), die kuberruim en sosiale media (Maree 2014; Von Solms 2013); klassieke vertaling (Vos 2015; Human 2016); kreatiewe skryfkuns (Du Plessis 2016); Afrikaanse spel- en skryfreëls (McLachlan 2011, 2012; Van Huyssteen en Kapp 2017), ens. Soms word werkwinkels of kort kursusse aangebied (Combrink 2015; Dykman 2012, 2013, 2015).

Hoewel Prolingua hoofsaaklik 'n vakvereniging vir Engelse en Afrikaanse taalpraktisyns is, woon taalpraktisyns wat in die ander amptelike tale werk ook die werksvergaderings by. Hulle word dan ook gereeld op die hoogte gehou van publikasies wat vir die Afrikatale van waarde kan wees, soos die onlangse publikasie oor teksredigering in Sesotho (Malete 2016) wat op Teksredaksie (Carstens en Van de Poel 2010) en Text Editing: A Handbook for Students and Practitioners (Van de Poel, Carstens en Linnegar 2012) gebaseer is. Hierdie Sesotho-weergawe is 'n Suid-Afrikaanse publikasie wat as pionier beskou kan word op die gebied van die standaardisering van 'n inheemse taal.

Prolingua (en sy voorgangers) het met die verloop van etlike jare verskeie termlyste en vakwoordeboeke in 'n Prolingua-termlys versamel. Nuwe terme uit verskillende vakgebiede word steeds in hierdie lys opgeneem. Die lys word gereeld bygewerk en hersien en is ' $n$ waardevolle hulpmiddel vir taalpraktisyns landwyd. Daar word soms ook termlyste saamgestel wat gratis op die webwerf (http://www.prolingua.org.za) beskikbaar gestel word (Prolingua 2015: 1).

Verskeie Prolingua-lede is ook medeouteurs van vakwoordeboeke: Business Dictionary/Sakewoordeboek (Geldenhuys en Viljoen-Smook 2009), Modern Political Dictionary/Nuwerwetse Politieke Woordeboek (Botha, Le Clus en Venter 2011) en Legal Terminology: Criminal Law, Procedure and Evidence/Regsterminologie: Straf-, Strafproses- en Bewysreg (CLTAL 2015). 
Verskeie lede en/of gassprekers het ook met verloop van jare aan die lede inligting verskaf oor wetgewing en wetsontwerpe wat op die taalberoep van toepassing is, soos die Nasionale Taalbeleidsraamwerk (Finale Konsep 2002); die Nasionale Taalbeleidsraamwerk en Implemeteringsplan (DKK 2003); die Taalbeleidsraamwerk van die Gautengse Provinsiale Regering (2005); die Kopieregwet (1978); die Kopieregwysigingswet (2002); die Wet op die Gebruik van Amptelike Tale (2012); die Suid-Afrikaanse Taalpraktisynsraad (2014); en die wysiging van hofbenamings (Le Roux 2016).

Tersaaklike inligting word ook aan lede verskaf deur 'n rubriek Taalwys wat per e-pos versprei en in die notules van die werksvergaderings opgeneem word. Lede word ook gereeld ingelig oor publikasies soos die Landdroshowe se boek met reëls in Afrikaans (VRA 2017) wat hul werk kan vergemaklik. Sulke publikasies is belangrik vir die regs- en taalprofessies omdat dit die gebruik van Afrikaans in die land se howe bevorder en belangrike regsterme regstegnies binne konteks (regsprosesse, -prosedures en wetlike betekenis) beskikbaar stel.

Verskeie gassprekers het tydens werksvergaderings inligting verskaf oor programmatuur wat gebruik word om terminologie te bestuur (Fourie 2014, Van Huyssteen 2014). Werkwinkels is ook deur lede aangebied oor programmatuur wat taalpraktisyns kan help om hul eie termlyste saam te stel en by te werk (Liebenberg, Delport en Greenfield 2016).

\section{Die Prolingua-termlys en ander produkte}

'n Ondersoek wat in 2015 in opdrag (SAAWK 2015a) van die Dagbreek Trust en die Suid-Afrikaanse Akademie vir Wetenskap en Kuns (SAAWK) afgehandel is oor die stand en status van Suid-Afrikaanse vaktaal (Alberts 2015a) wys daarop dat Afrikaanse vaktaal gedurende die vorige bedeling (en veral vanaf 1950 tot 1994) 'n bloeitydperk beleef het (Alberts 2000a en b; Alberts 2015a en b). Die huidige Suid-Afrikaanse Grondwet (1996) vereis by implikasie dat aandag gegee word aan die ontwikkeling van meertalige vaktaal. Die vaktale van die amptelike tale moet in die toekoms saam ontwikkel word - nie net vir eie behoud en ontwikkeling nie, maar veral weens vakgerigte kommunikasiebehoeftes.

Tans is die meeste tweetalige vakwoordeboeke wat in die verlede deur (vak)taalkantore en individue saamgestel is, uit druk. Daar is geen sin daarin om hierdie ou tweetalige vakwoordeboeke in hardebandformaat te herproduseer nie aangesien die klem deesdae op die samestelling van meertalige termlyste en aanlyn terminologiese produkte val. Vaktaalbronne wat wel beskikbaar is, soos termlyste, vakwoordeboeke en termdatabasisse, is by verskillende staats- en semistaatsdepartemente, instansies en in biblioteke of êrens by private persone. Hierdie fragmentering maak dit uiters moeilik om beskikbare vaktaalbronne op te spoor en potensiële vaktaalgebruikers is dikwels onbewus dat bronne wat hulle nodig het, weliswaar bestaan (Luther 2005). 
As gevolg van die beperkinge wat die huidige talesituasie op veral Afrikaanse vaktaalontwikkeling plaas, is dit ook heel onwaarskynlik dat hierdie vakwoordeboeke ooit herdruk sal word. Aangesien baie belastingbetalergeld, vak- en taalkundige insigte en werk in die samestelling van hierdie vakwoordeboeke gegaan het, sal dit 'n onreg wees as hierdie vaktaalinligting verlore sou gaan. Die vaktaalinligting is steeds geldig. Die terme is grootliks reeds gestandaardiseer en baie min daarvan kan as verouderd beskou word. Die terminologieskat is steeds bruikbaar vir vakspesialiste, joernaliste, leerders, onderwysers en studente en taalpraktisyns soos vertalers, tolke, terminoloë, leksikograwe, taaldosente, onderwysers, ens. Taalpraktisyns wat hoofsaaklik in die Afrikatale werk, maak ook van Engels-Afrikaanse vakwoordeboeke gebruik in termskepping. Hulle kan konseptuele inligting soms makliker uit die Afrikaanse definisies ontsluit en skep terme na aanleiding van die Afrikaanse termekwivalente eerder as die Engelse terme (Alberts 2015a). Hoewel die Prolingua-termlys dus slegs tweetalig is, is dit ook van waarde vir die gebruikers van die ander amptelike tale.

Die gedigitiseerde Prolingua-termlys dateer uit 1984. Van die terme wat vóór 1984 deur Prolingua se voorgangers gedokumenteer is, is ook in die Prolingua-termlys opgeneem. Sommige terme wat in hierdie termlys opgeneem is, is nêrens in vakwoordeboeke opgeteken nie en die lys is dus 'n waardevolle terminologiese bron (Prolingua 2015: 3).

Mnr. Pieter Taljaard, voorheen verbonde aan die Poskantoortaaldiens, het na sy aftrede in sy hoedanigheid as voorsitter van Prolingua verskillende instansies besoek, o.a. die Nasionale Terminologiediens, Departement van Kuns, Kultuur, Wetenskap en Tegnologie (tans die Terminologiekoördineringsafdeling, Nasionale Taaldiens, Departement van Kuns en Kultuur) en die Suid-Afrikaanse Akademie vir Wetenskap en Kuns om te verneem of Prolingua die data van hul gepubliseerde woordeboeke kon benut deur die data te skandeer en dan in elektroniese formaat aan vertalers en vaktaalgebruikers beskikbaar te stel. Prolingua het die nodige toestemming om die data te benut van die meeste uitgewers, vakwoordeboeksamestellers en vaktaalkantore bekom en die outeursreg is opgehef. Waar moontlik is die inligting elektronies aan Prolingua verskaf (Alberts 2015a).

Die samestelling van die Prolingua-termlys is 'n projek sonder winsbejag en alle wins uit die aanvanklike verkope van die termlys is vir die verbetering van die produk aangewend. Die Prolingua-termlys was aanvanklik slegs vir lede toeganklik en hersiene, bygewerkte termlyste is gereeld elektronies aan lede gestuur en drukstukke kon ook op aanvraag gemaak en verkoop word.

Dit blyk duidelik uit voorgaande dat Suid-Afrikaanse terminologie grotendeels met behulp van belastingbetalergeld ontwikkel, gedokumenteer en gedissemineer is (Alberts 2015a). Die hoofbron vir die Prolingua-termlys was ou vakwoordeboeke en termlyste wat deur staatsinstansies saamgestel is en goedgunstig aan Prolingua beskikbaar gestel is. Daar was dus eintlik geen rede waarom die terme nie gratis aan alle (vak)taalgebruikers beskikbaar gestel kon 
word nie. Die belastingbetalers, dus (potensiële) vaktaalgebruikers, het immers reeds daarvoor betaal. Die terminologie in die Prolingua-termlys kan vir ander taalpraktisyns soos vertalers, redigeerders, terminoloë en tolke en vakspesialiste van nut wees en is tans gratis op Prolingua se webwerf http://www. prolingua.org.za beskikbaar. Tans word nuwe terme uit verskillende vakgebiede in die Prolingua-termlys opgeneem en gereeld deur die lede hersien of bygewerk.

Die volgende doelwitte van Prolingua rig sy aktiwiteite rondom terminologieontwikkeling:

- om terme sover moontlik te standaardiseer;

- om die gehalte van vertaalwerk te verbeter; en

- om lede die geleentheid te gee om hul vertaal- en terminologieprobleme te bespreek, met die Prolingua-termlys as die uiteindelike uitkoms van hierdie besprekings (Prolingua 2015: 3).

In die afgelope 67 jaar het Prolingua buiten die Prolingua-termlys ook vele ander termlyste saamgestel. Termlyste is saamgestel vir elektrisiteit; stadsbeplanning asook pad en vervoer; name van organisasies; name van kwalifikasies; name van wette en ander terme. Prolingua-lede het ook aan die saamstel, hersiening en bywerking van etlike vakwoordeboeke meegewerk. Hierdie vakwoordeboeke sluit in: Brandweerwoordeboek; Elektrotegniese en Elektroniese woordeboek; Kernbedryfwoordeboek; Lewensversekeringwoordeboek; Opmeetwoordeboek; Plastiekwoordeboek; Poskantoorwoordeboek; Stadsbeplanningswoordeboek; Terminologie van vergaderingsprosedure en redevoering; Tweetalige Voorsetselwoordeboek; Water- en rioolwerketerme; Insekname- en Skoenlapperlys. Heelwat van dié vakwoordeboeke is uit druk en daar is toe begin om hulle elektronies in te lees en gevolglik is heelwat van hierdie vakwoordeboeke steeds by Prolingua in elektroniese formaat beskikbaar (Prolingua 2015: 3).

Prolingua tree ook proaktief op en 'n lys van ongeveer 300 Gautreinterme is op die Prolingua-webwerf beskikbaar. Een van die Prolingua-lede, Johan Dorfling, het 'n unieke Brugwoordelys saamgestel waarvoor hy self Afrikaanse brugterme geskep het. Hy het 'n behoefte aan Afrikaanse terme vir die brugspel geïdentifiseer en die termlys gevolglik geïnisieer, saamgestel en bygewerk (Prolingua 2015: 3; Dorfling 2002-2011).

Al hierdie vakgebiede waarby Prolingua betrokke is (hetsy deur die bewaring of skep van terme), toon dat elke vakgebied, hoe gespesialiseerd of eenvoudig ook al, oor 'n unieke stel terme beskik wat bepaalde begrippe uniek benoem en belangrik is vir vakkommunikasie. Terminologieontwikkeling is belangrik vir elke vakgebied en staan voorop in die ontwikkeling van enige taal tot funksionele gebruiks- en wetenskapstaal (Alberts 2003: 128; Alberts 2015a).

\section{Terminologieontwikkeling deur Prolingua}

Terminologie word nie net deur vakkundiges, vertalers, tolke, joernaliste, teg- 
niese skrywers en woordeboekmakers benodig nie, maar ook deur onderwysers, leerders, dosente, studente, staatsamptenare, sakelui, medici, regslui, skoenmakers, kuipers en alle ander beroepslui. Vaktaalgebruikers het nie net terme, termekwivalente en definisies of verklarings nodig nie, maar ook gebruiksvoorbeelde wat die gebruik van ' $\mathrm{n}$ term in verskillende registers aantoon. Hoewel terminoloë poog om konsepte eenduidig met slegs een term/termekwivalent te benoem (die beginsel van een konsep een term), is dit tog soms nodig om sinonieme te verskaf (byvoorbeeld by Afrikaanse terme die Germaanse vorm naas 'n getranslitereerde vorm). Taalpraktisyns benodig soms sinonieme vir ' $n$ bepaalde konteks asook ' $n$ aanduiding van die registers waarin ' $n$ bepaalde term of sy sinonieme gebruik sou kon word. Hulle benodig uiteraard ook die heel jongste terminologie.

Wanneer doeltreffende kommunikasie op en oor 'n spesifieke spesialisveld onmoontlik raak, omdat die taalgebruikers nie oor die nodige terme in die moedertaal beskik nie of nie weet waar om die regte terme te vind nie, is daar geen keuse nie as om na Engels oor te slaan (Luther 2005). Almal kla oor die hegemonie van Engels, maar min pogings word werklik gekoördineerd aangewend om die vaktale van die verskillende vakterreine in die amptelike tale te ontwikkel. Die lede van Prolingua poog om ten minste aandag te gee aan die ontwikkeling van Afrikaanse terme en hierdie terme is beskikbaar en bruikbaar en toeganklik vir gebruik deur enige ander taalgroep wat termekwivalente na aanleiding van die Afrikaanse terme wil skep.

\subsection{Prolingua-lys: hersiening en bywerking}

Die Prolingua-termlys is ' $n$ tweetalige alfabetiese lys met Engels as brontaal en Afrikaans as doeltaal. Geen verklarings van terme word voorsien nie, maar verbandswoorde gee wel waar nodig ' $n$ aanduiding van vakgebied of kontekstuele gebruik.

Die Prolingua-lede hersien die Prolingua-lys gereeld tydens werksvergaderings. Die lysie terme wat tydens 'n bepaalde werksvergadering vir hersiening aan bod kom, word vooraf per e-pos aan lede gestuur sodat lede wat nie die vergadering kan bywoon nie ook die geleentheid te baat kan neem om insette te lewer. $\mathrm{Na}$ afloop van die werksvergadering word die databasis deur Fritz Wolff, 'n voormalige voorsitter van Prolingua, bygewerk.

Enkele voorbeelde van terme wat aan bod gestel word vir hersiening tydens 'n werksvergadering (Prolingua (IvB) 2017b):

bricks and mortar industry \{physical industry\}: stene-en-daghabedryf

brickyard (brick works, brickfield): steenmakery

bright $v$. \{vehicle headlights\}: helder

brilliant cut diamond: briljant

broadbanding \{staff management\}: bandverbreding

broad-based \{economics and social work\}: breëbasis-

broad-based black economic empowerment (BBBEE): breëbasis swart ekonomiese bemagtiging, BBSEB 
broadside \{advertising\}: voubiljet

brokerage (broking) \{eg insurance\}: makelaarsbedryf

brokerage $\{$ firm\}: makelary, makelaarsmaatskappy

brokerage: kommissie, makelaarsloon

broking (brokerage) \{eg insurance\}: makelary

Enkele voorbeelde van probleemterme wat deur lede voorgelê word vir bespreking tydens ' $n$ werksvergadering (Prolingua (IvB) 2017a):

picketing (groep mense wat staak deur byeen te kom en doodstil met plakkate staan en protesteer): betooglinievorming (Wet op Arbeidsverhoudinge, 66 van 1995/Labour Relations Act 66 of 1995): Artikel 69 5(a) and (6); Vloeidiagram/Section 69 5(a) and 6.

picketing: betooglinievorming

picket $n$. : betooglinie

picket $v$. : om ' $n$ betooglinie te vorm

Voorstelle vir Afrikaanse termekwivalente: picketing: staakwag, brandwaglinie (Pharos); protesstanery

penalising (Example sentence: In such cases, a court can grant a more penalising division or maintenance order than it would normally do if it were of the view that one spouse is in control of significantly more trust assets.)

Voorstelle vir Afrikaanse termekwivalente: bestraffende, strafbare, penaliserende, straffende (punitive $=$ bestraffende $($ CLTAL 2015))

lockout/tagout $\{$ beroepsveiligheid en -gesondheid\} 'Lockout' is wanneer werkers fisies 'n kragskakelaar sluit sodat dit nie aangeskakel kan word wanneer iemand daaraan werk of aan iets wat daaraan gekoppel is nie en 'tagout' is wanneer daar 'n etiket aan die geslote ding geheg word.

lock-out switch: afsluitskakelaar (Pharos)

Voorstelle vir Afrikaanse termekwivalente: afsluitingsetiket, afsluitingskaartjie, afsluitingsmerk

\section{master account billing}

Voorstelle vir Afrikaanse termekwivalente: meesterrekeningfakturering, meesterrekeningdebitering

Die volgende terme is tydens werksvergaderings bygevoeg, gewysig of geskrap (Prolingua 2016; 2017a):

board $v .:$ medies ongeskik verklaar aftree, board [someone is boarded/ iemand medies laat aftree

bodyies of knowledge: kenniskorpuscorpora, kennisinhoude [Onderwysterme][Mrt12] 
body \{eg oil\}: lywigheid, viskositeit

body (generall): romp

body [nobody/te dun]:-

body language: liggaamstaal, lyftaal

body of knowledge: kenniscorpus, kennisinhoud

[Onderysterme][Mrt12]

body surfing: branderry

body surfing: branderry, lyfbranderry

boggle [it boggles the mind, the mind boggles at/dit slaan my dronk]:-

bogie \{railway truck\}: begie, draaistel

boil off (degum): afkook

bone mass density scan: beenmassadigtheidsenderseek,

beenmassadigtheidskandering

boob tube: buisbostuk, buistoppie, spantoppie

booby prize: fopprys, spotprys

boogie board: lyfplank

boomtown: snel groeiende stad, snel groeiende dorp [Feb2006]

bottom line: eok netto wins

brain drain: kundigheidsverlies, breindrein

brain writing: skryfskrum breinskrif

brainstorm $v$.: dinkskrum [colloquially — harsingsgalop, kopgalop]

brainstorming session: dinkskrum, ideestorm, ideeberaad

brand manager: produkmerkbestuurder \{bankwese

branded bottled water: gebottelde handelsmerkwater

branding: naamreklame, beeldbemarking, handelsmerkvestiging [Mei09], handelsmerkgewing

breeding camp \{for game\}: teelkamp [hupskamp-slegs in nietegniese, laeregistergebruik]

breëkoparend: martial eagle [Feb2006]

\subsection{Termskepping}

Prolingua se gebruik om gassprekers by geleentheid na werksvergaderings (of soms na die algemene jaarvergadering) uit te nooi om Prolingua-lede oor verskeie terminologiekwessies toe te spreek, dra daartoe by dat die lede insae kry in verskillende terminologieverwante sake soos termskepping, standaardisering en harmonisering.

Van die aspekte wat in die onlangse verlede veral onder die loep gekom het, is terme van klassieke herkoms, neologismes en die waarde van die standaardisering en harmonisering van terminologie.

\subsubsection{Terme van klassieke herkoms}

Die invloed van die klassieke tale op terminologieontwikkeling is deur verskeie gassprekers beklemtoon. 
Die vertaling van die Bybelse frase 'klinkende metaal' (1 Kor 13:1) is 'n voorbeeld waar die Griekse en Latynse herkoms van 'n terminologiese frase nagespoor word en veroorsaak dat die terminologiese frase dan later tydens die hersiening van tekste (byvoorbeeld Bybeltekste) gewysig word na byvoorbeeld 'galmende ghong' (Proefvertaling van 2005) en later (in beplande 2018vertaling) as 'weergalmende ghong' (Human 2016). Die terminologiese frase verwys moontlik na akoestiese vase wat deur die Romeine in teaters gebruik is om as klankversterkers vir akteurs en sangers te dien - hierdie klankversterkers is selfs gebruik om donderweer te verklank en sou dus 'weergalmers' genoem kon word. Die Griekse woorde chalkos echōn beteken letterlik koper/ geelkoper/brons- + galmend/weergalmend/wat eggo. Die Afrikaanse term 'ghong' is veral bekend as die musiekinstrument waarmee etenstye in treine aangekondig word.

Dikwels is woorde of terme alreeds sodanig in ' $n$ taal of tale ingebed dat dit soms moeilik is om te bepaal of hulle uit Grieks of Latyn afgelei is (Bosman 2015), byvoorbeeld:

Eng catastrophe / Afr katastrofe $>$ kata (onder) + strophe (draai) = draai daar onder

Eng atmosphere / Afr atmosfeer $>$ atmos (damp) + sphaino (bal)

Eng manipulate / Afr manipuleer $>$ manus (hand) $=$ speel (iemand) na my hand

Eng politics / Afr politiek $>$ polis = gemeenskap /dorp/stad)

Voorbeelde van terme wat klaarblyklik uit Grieks ontleen is (Bosman 2015), is die volgende:

Eng metaphore / Afr metafoor > Grieks: meta (prefiks: langs of onder) + pherein $/$ phore $(\mathrm{dra})=$ dra langs $/$ in die plek van iets anders

Eng synonym / Afr sinoniem > Grieks: syn (prefiks: saam) + onoma $($ naam $)=$ "saam naam", dieselfde naam, die een is soos die ander

Eng syntax / Afr sintaksis > Grieks syn (prefiks: saam) + tasso (organiseer $)=($ woorde) saam rangskik (in 'n sin)

Voorbeelde van terme wat klaarblyklik uit Latyn ontleen is (Bosman 2015), is die volgende:

Eng suffix / Afr suffiks > Latyn: sub (prefiks: onder, end) + figo (bind) = "bind by einde"

Eng suspicion / Afr suspisie > Latyn sub (prefiks: onder, end) + spectare $(\mathrm{kyk})=$ kyk daar onder (waar ek iets verwag)

Dit is egter veral in die mediese en regsberoepe waar terme wat uit die klassieke tale ontleen is, voorkom. Volgens Bosman (2015) is die mediese terme van die 21ste eeu gevestig in liggaamsbelewinge en waarnemings van mense wat 2000 tot 3000 jaar gelede gelewe het. So ervaar mense vandag soortgelyke liggaamlike gebreke en gesondheidstoestande as 2000 plus jaar gelede. Die mense 
van die toekoms gaan steeds afhanklik wees van dieselfde geestelike gawe van kommunikasie (taal) as vandag en 2000 jaar gelede. Die moderne mediese terme huisves dus 'n verskeidenheid aspekte tiperend van hoe die mens 2000 jaar gelede die lewe, gesondheid en siektes ervaar het, hoe hulle gedink het, hulle kultuur en tradisies beleef het, hul logiese en filosofiese denke en hulle mitiese of godsdienstige ingesteldheid tot die lewe. Sonder inagneming van bogenoemde aspekte is dit nie altyd moontlik om moderne mediese terme se oorsprong en betekenis te verstaan nie. Voorbeelde van terminologie in die mediese beroep wat duidelik bogenoemde redenasie verteenwoordig is:

melancholia (Afr: melankolie) (letterlik: 'toestand van swart gal'; depressie, swartgalligheid). Konteks: swart = boos; gal hou verband met die tradisionele siening dat die gees/verstand in die maag gesetel is en word dus met die maag se kernfunksie (gal) verbind.

maag word ook met diafragma (phren) (spier wat dwars sluit) verbind.

phren: 1 diafragma 2. gees, verstand

hypochondria (letterlik: onder kraakbeen (bors); maag; diafragma — waar die gees/verstand is): siektetoestand van die gees/kop/verbeelding/ verstand. Afr: hipokondria; volksetimologie: iepekonders

phrenoplegia (Afr frenoplegie): 1. Verlamming van die diafragma, diafragmaparalise 2. Aanval van geestesiekte

schizophrenia (Afr: skisofrenie): $\mathbf{s h i z}=$ oopkloof $/$ gesplete + phren $=$ gees, verstand (letterlik: gesplete gees/verstand)

Mediese terme word gewoonlik saamgestel met behulp van die klassieke stamvorm plus prefikse en suffikse. Voorbeelde hiervan is die volgende (vgl. Bosman 2015):

facioplasty (facio: gesig + plast: herstruktureer, verbetering): plastiese chirurgie van die gesig; soortgelyk: stomatoplasty (mond-); rhinoplasty (neus-); cheiroplasty (hand-)

sigmoid colon $($ sigma $=$ Griekse letter $\mathrm{S}$, dus $\operatorname{sigm}(\mathrm{a})(\mathrm{S})+$ oid $=$ soos): laaste deel van die kolon voor die rektum wat s-vormig is.

thyroid gland (Grieks: thyre $($ os) $=$ skild + iod = soos): skildklier

Dit is egter nie net op die mediese terrein waar terme van klassieke herkoms benut word nie. Die regsprofessie wemel van Latynse terme en frases. Hierdie terme en frases is dikwels ontoeganklik vir gebruikers. Latynse terme wat onveranderd in Engels en Afrikaanse regstaal ingebed is, word kortliks omskryf ter wille van gebruikers wat nie Latyn magtig is of oor die nodige regskennis beskik nie (Alberts 2012; CLTAL 2015):

Eng: prima facie (on the first impression) Eng: pro forma (as a matter of form)
Afr: prima facie (op die oog af) Afr: pro forma (ter wille van die vorm) 
Sommige Latynse regsterme word onveranderd in Engels en Afrikaans gebruik, maar van sinonieme voorsien (Alberts 2012), byvoorbeeld: Eng: dolus (intention) Afr dolus (opset) $\begin{aligned} & \text { Noord-Sotho dolus } \\ & \text { (maikemisetso) }\end{aligned}$

Voorbeelde van Latynse frases wat in die regte gebruik word (Alberts 2012):

sine die [Latin, without a day being fixed] : sine die [Latyn, sonder dat ' $n$ dag vasgestel is]

situs $n$ location or position of something for legal purposes, e.g. the place where a crime or accident occurred [Latin, location] : situs $n$ ligging of posisionering van iets vir regsdoeleindes, bv. die plek waar ' $n$ misdaad of ongeluk gebeur het [Latyn, ligging]

\subsubsection{Hersiening of wysiging van terme}

Regstaal is daarvoor bekend dat dit 'n magtige instrument is wat aangewend kan word om in te sluit of uit te sluit. Regsjargon is eiesoortig en veroorsaak groot begripsprobleme vir verskillende doelgebruikers - nie net vir regsgeleerdes nie, maar ook vir leke. Volgens huidige wetgewing het almal die reg op inligting in gewone en verstaanbare taal en dit vereis verder dat inligting aan gebruikers in gewone taal beskikbaar gestel moet word (Cornelius 2012). Voorbeelde van terme waar inligtingsdigtheid verstaan- en leesbaarheid beïnvloed, is

korttermynversekeringspremies eerder: premies vir korttermynversekering

aankoopkaartbeskermingsfonds eerder: kaartbeskermingfonds

kredietopnemerlidmaatskap eerder: lidmaatskap

herskikkingsooreenkoms eerder: ooreenkoms om skuld af te betaal

Baie Prolingua-lede werk in staats- en semistaatsdienskantore en moet gevolglik vertroud wees met die jongste wetgewing. Verskeie benamings van die land se howe is gewysig en die jongste benamings is vervat in die Wet op Hoër Howe, 2013, Wet 10 van 2013. Voorbeelde van die belangrike howe se benamings is (Le Roux 2016):

Constitutional Court / Konstitusionele Hof

Supreme Court of Appeal / Hoogste Hof van Appèl

High Court of South Africa / Hooggeregshof van Suid-Afrika

Superior Court / Hoër Hof

Circuit Courts / Rondgaande howe

Magistrates' Court / Landdroshof

Die benaming van die land se howe lewer dikwels vir gebruikers probleme op 
omdat dié terme dikwels gewysig word sonder dat die meeste mense van die wysigings bewus is en soms selfs foutief in vakwoordeboeke opgeneem word (CLTAL 2015), vgl. in hierdie verband hooggeregshof (van 1909) wat gewysig is na hoë hof (1997) en sedert 2013 weer bekend is as hooggeregshof (SRTATdatabasis 2017).

\subsubsection{Neologismes}

Prolingua se doelstellings is om terme te voorsien, te standaardiseer en vertaalprobleme op te los. Voorbeelde van Afrikaanse neologismes in die Prolinguatermlys (Prolingua 2015) is:

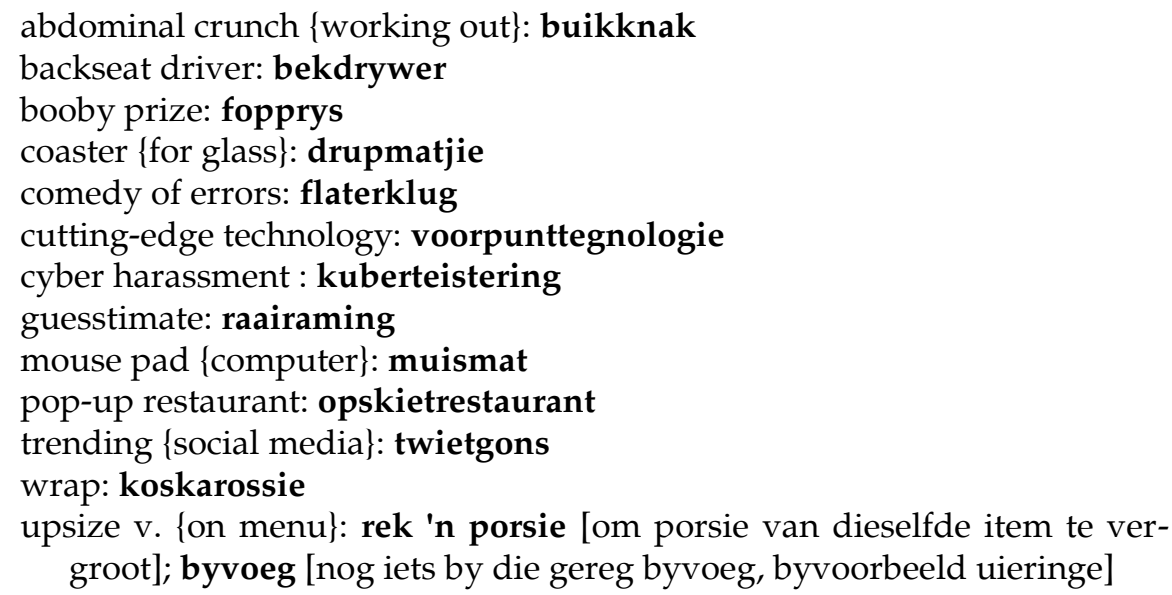

Prolingua se gassprekers het egter ook grootliks daartoe bygedra om neologismes onder die aandag van lede te bring. Hierdie nuutskeppings brei nie net die Afrikaanse terminologieskat uit nie, maar hulle bevorder die Afrikaanse taal op 'n kleurryke wyse. Enkele voorbeelde van nuutskeppings in verskillende vakgebiede wat deur gassprekers en medewerkers voorsien is, is die volgende:

Brugterme: Daar is 'n toenemende belangstelling onder Afrikaanssprekendes om brug te speel. Veral tuisspelers en etenstydspelers het die afgelope aantal jare talryker geword en aldus het die behoefte aan 'n saamgestelde termlys al hoe sterker geword. Daar bestaan wel goeie Afrikaanse terminologie, maar betreklik min brugspelers is op die hoogte daarvan omdat dit nêrens versamel is of maklik nageslaan kan word nie. Een van die Prolingua-lede, Johan Dorfling, het 'n Brugwoordelys saamgestel waarvoor hy self Afrikaanse termekwivalente geskep het. Hy het die proses om die brugtermlys saam te stel self geïnisieer en die lys verskeie kere hersien en bygewerk. Die oogmerk van die samesteller van die brugtermlys is om die groot leemte aan 'n eenvormige en volledige Afrikaanse woordeskat vir brugspelers aan te vul (Dorfling 2002; 2012). 
In die soeke na meer volledige en bruikbare termekwivalente vir Afrikaans is daar onder meer by Vlaams, Nederlands en Duits kers opgesteek om Afrikaans sodoende te verryk en die Germaanse inslag van Afrikaans te behou. Versigtigheid is egter aan die dag gelê om nie terme op te neem wat met die taaleie bots nie. Sommige brugterme wat in Nederlands gebruik word, het nie inslag in Afrikaans gevind nie. Dié terme, wat weliswaar in ander Afrikaanse woordeboeke verskyn, is aanvanklik in die brugtermlys opgeneem, maar in latere weergawes weggelaat omdat dit enersyds nie deur Afrikaanssprekendes gebruik word nie en andersyds nie in die Afrikaanse idioom pas nie. Een voorbeeld is die benaming blindeman wat teenoor die troefmaker sit. Hierdie speler is in geen opsig "blind" nie, nie letterlik of figuurlik nie. Die speler beweeg in die skadu van die troefmaker en die benaming skaduspeler is meer gepas en word in die algemeen so gebruik.

Regstreekse vertaling vanuit Engels is dikwels nie aanvaarbaar of duidelik nie. So beteken "cancelled call" byvoorbeeld volgens die Engelse spelreëls van brug dat ' $n$ roep ongeldig is en nie dat dit 'ingetrek' is nie. Die benaming "international match point" is ook verwarrend omdat dit nie 'n werklike beskrywing van die telwyse is nie en 'n direkte vertaling daarvan te lank is om inslag te vind. Die term "international match point" word meermale ook op plaaslike vlak toegepas en is in werklikheid 'n glytelling. Glytelling is dan ook die term wat by Afrikaanssprekende brugspelers byval gevind het.

Johan Dorfling is in 2014 deur Prolingua by die algemene jaarvergadering vir hierdie waardevolle bydrae tot die Afrikaanse terminologieskat met ' $n$ spesiale toekenning vereer. Die Brugwoordelys is op die Prolingua-webwerf (www. prolingua.org.za) beskikbaar.

Regsterme: Die werksaamhede van die Sentrum vir Regsterminologie in die Afrikatale (SRTAT) is by 'n Prolingua-werksvergadering bespreek (Alberts 2012). Die projek het ontstaan toe vertalers en tolke van die destydse selfregerende state in Suid-Afrika by die algemene jaarvergadering van die Suid-Afrikaanse Vertalersinstituut (SAVI) in 1985 aangedui het dat hulle terminologieprobleme ervaar wanneer regsdokumente vertaal word, wetgewing vir die verskillende state opgestel word en daar in die hof getolk moet word aangesien regsterminologie in die Afrikatale óf nie bestaan nie óf ontoereikend is. Daar is eerste met Noord-Sotho begin omdat taalpraktisyns wat in dié taal werksaam is die probleem die eerste aan bod gestel het. Die volgende Noord-Sotho of Afrikaanse nuutskeppings is in die SRTAT-databasis opgeneem:

Engels
baby snatcher
bush lawyer
parental kidnapping
premeditated crime
primary evidence
polygraph

Engels parental kidnapping primary evidence polygraph

\author{
Noord-Sotho \\ seutswalesea \\ moitiraramoloa \\ tšhabišokamotswadi \\ bosenyipeakanywa \\ bohlatsehlatse \\ seutoliamaaka
}

\author{
Afrikaans \\ babadief \\ bosprokureur \\ ouerontvoering \\ voorbedagte misdaad \\ beste getuienis \\ poligraaf
}


Die Sentrum se regswoordeboek Legal Terminology: Criminal Law, Procedure and Evidence/Regsterminologie: Straf-, Strafproses- en Bewysreg is in 2015 deur Juta gepubliseer en tans word die finale afronding aan die Noord-Sothoweergawe van die woordeboek gedoen. Die Sentrum het ook reeds begin met die byvoeging van terme en definisies in die ander amptelike Afrikatale.

Rolprentterme: 'n Gasspreker, Leon van Nierop, het die Prolingua-lede tydens 'n werksvergadering op 'n reis deur die rolprentwêreld geneem deur 'n lys Engels-Afrikaanse terme wat op rolprentstel gebruik word vir bespreking voor te lê. Die lede kon daardeur uitvind wat elke persoon se taak gedurende die vervaardiging van ' $n$ film is en wat die verskillende rolprentprosesse behels. Die aanbieding het ook aangedui wat die titellys, wat aan die einde van ' $n$ rolprent rol, beteken. Dit was ' $n$ interaktiewe sessie waar Prolingua-lede insette kon lewer oor die korrekte spelling van woorde (veral los- en vasskryf) en voorstelle vir vertalings kon maak. Enkele voorbeelde van die rolprentterme wat bespreek is, is die volgende (Van Nierop 2016):

\section{Titels}

datahanteerder

digitale fasiliteerder

kinematograaf

klankhengelaar

lokprentredigeerder

lynvervaardiger

rolverdelingleser

steadicam-operateur

takelaar

uitvoerende vervaardiger

\section{Titles}

data handler, data coordinator digital facilitator

cinematographer

boom swinger

trailer editor

line producer

cast reader

steadicam operator

grip

executive director

Ander interessante rolprentterme wat bespreek is, is die volgende:

byklanke
dolly (spoortrollie)
doof in en doof uit
filmmateriaal
fokustrekker
glyskoot
jibarm
klankkring
naproduksieklankfasiliteit
vriesraam

foley

dolly

fade in and fade out

footage

focus puller

tracking shot

jib

looping of sound

post production sound facility

freeze frame

Radiotegnologie en radioterme: Dit is nie net taalpraktisyns wat ' $n$ belangrike bydrae tot Afrikaanse terminologieontwikkeling lewer nie. Dit is duidelik bewys deur die aanbieding oor radiotegnologie en radioterme tydens 'n Pro- 
lingua-werksvergadering (Burger 2016). Burger het die SA Radioliga se Engelse studiegids geredigeer, herrangskik en bygewerk. Die studiegids is daarna op die liga se webwerf geplaas en in gebruik geneem. Nadat die SA Radioliga besluit het dat hulle eksamens voortaan slegs in Engels afgelê gaan word, aangesien die handleiding in Engels is, het Burger besluit om die gids in Afrikaans te vertaal. Hy het die hoofstukke wat die basiese grondslag dek, vertaal, en vir die meer tegniese hoofstukke slegs termlyste saamgestel. Op grond van hierdie werk van hom, is daar besluit dat die eksamens steeds in Afrikaans afgelê kan word. Van die 25 hoofstukke in die studiegids is 15 op suiwer elektronikateorie toegespits en dus op verskeie vakgebiede van toepassing. Om hierdie rede gebruik skole in Mpumalanga die studiegids as deel van die graad 12-Elektronikaleerplan.

Wat die vertaling bemoeilik het, is dat die radio- en elektronikawoordeboeke in Afrikaans reeds verouderd is. Dit is ' $n$ veld waarin terme vinnig ontwikkel en verander. Burger het sover as moontlik probeer om Germaanse terme te skep en anglisismes te vermy. Hy het byvoorbeeld verkies om die volgende Afrikaanse terme op te neem:

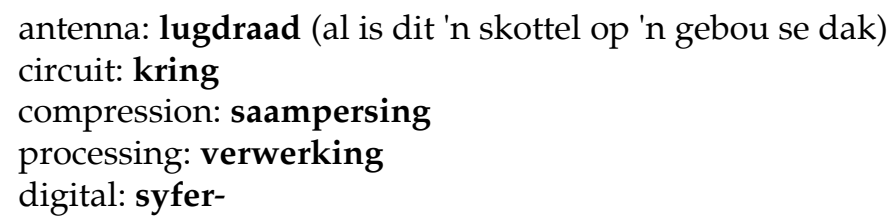

Die termlys word gereeld bygewerk en dit is gratis beskikbaar by: http:// zs6ez.org.za/download/RadioWoordelys.pdf.

Sportterme: Die bekende sportverslaggewer, Johann Russouw, het tydens ' $n$ Prolingua-werksvergadering oor Afrikaanse sportterme gesels wat oor die radio gebruik word. Hy het veral op voetbal (sokker), gholf, krieket, rugby, swem en atletiek gekonsentreer wat vol eiesoortige Afrikaanse nuutskeppings is. Interessante sportterme wat tydens die aanbieding aan bod gekom het, is die volgende (Russouw 2017):

$\begin{array}{llll}\text { Atletiek: } & \text { gewigstoot (shot put) } & & \\ \text { Gholf: } & \begin{array}{l}\text { afslaan (tee shot) } \\ \text { sandkuil (bunker) }\end{array} & \begin{array}{l}\text { skoonveld (fairway) } \\ \text { setperk (putting green) }\end{array} & \begin{array}{l}\text { sukkelveld (rough) } \\ \text { baansyfer (par) }\end{array} \\ \text { Tennis: } & \begin{array}{l}\text { snyhou (slice) } \\ \text { gelykop (deuce) }\end{array} & \begin{array}{l}\text { valhou (drop shot) } \\ \text { vlughou (volley) }\end{array} & \begin{array}{l}\text { mokerhou (smash) } \\ \text { lughou (lob) }\end{array} \\ & \begin{array}{l}\text { trutol (back spin) } \\ \text { skoon stel(le) (straight set(s)) }\end{array} & \\ \text { Krieket: } & \begin{array}{l}\text { gang (gully) } \\ \text { skerpby (short leg) }\end{array} & \begin{array}{l}\text { dekpunt (cover) } \\ \text { vlakby (silly mid-on) }\end{array} & \begin{array}{l}\text { regby (square leg) } \\ \text { vlak (silly mid-off) }\end{array}\end{array}$




\begin{tabular}{|c|c|c|c|}
\hline Rugby: & $\begin{array}{l}\text { doelpale (upright) } \\
\text { plettervat (crash tackle) } \\
\text { rolskop (grubber kick) }\end{array}$ & $\begin{array}{l}\text { laagvat (tackle) } \\
\text { skrumskakel (scrumhalf) } \\
\text { pynpolisie (first-aid staff) }\end{array}$ & skepskop (drop kick) \\
\hline $\begin{array}{l}\text { Voetbal/: } \\
\text { Sokker }\end{array}$ & $\begin{array}{l}\text { sweefbal (floater) } \\
\text { soolknoppie (stud) }\end{array}$ & $\begin{array}{l}\text { doelskut (striker) } \\
\text { wawielskop (bicycle kick) }\end{array}$ & neerbring (tackle) \\
\hline
\end{tabular}

Lugvaartterme: Die volgende lugvaarterme (waarvan sommige in konteks gebruik is), is deur 'n medewerker aan Prolingua beskikbaar gestel (Van Huyssteen 2017):

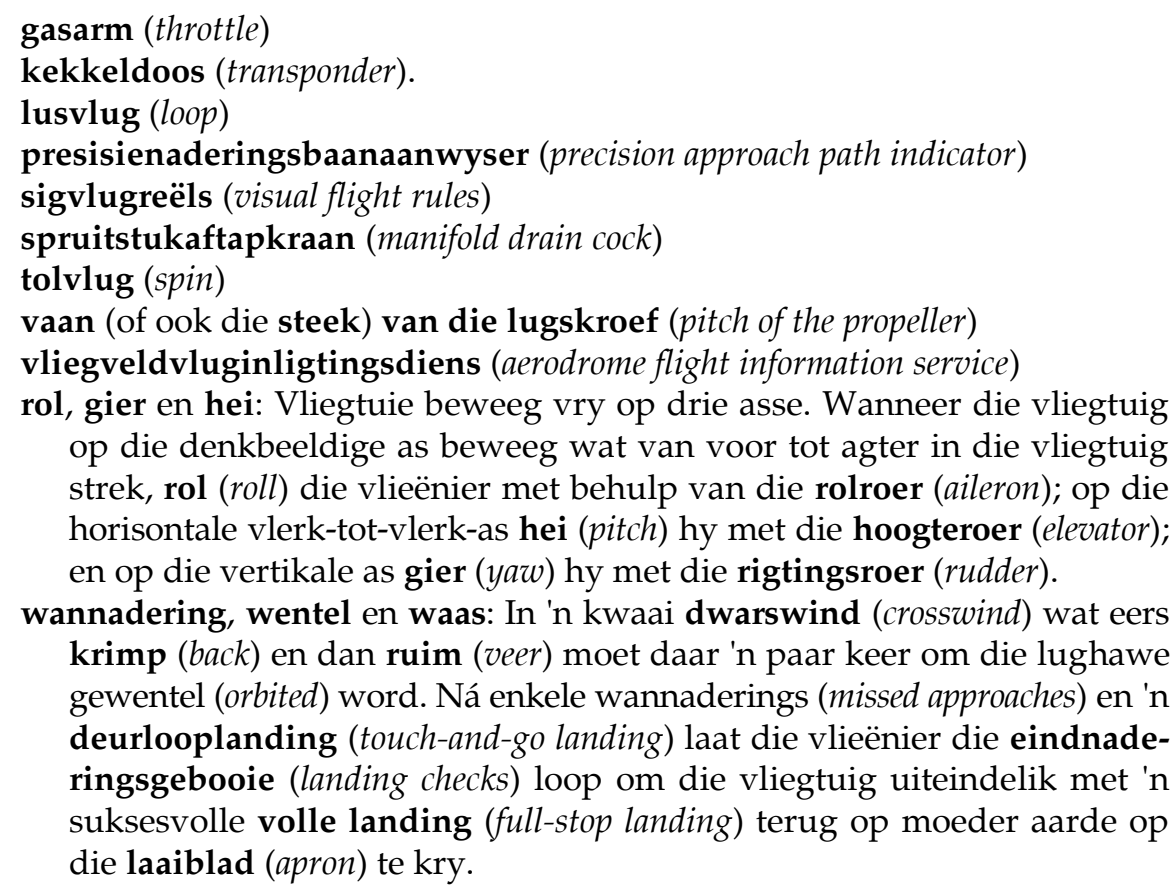
op die denkbeeldige as beweeg wat van voor tot agter in die vliegtuig strek, rol (roll) die vlieënier met behulp van die rolroer (aileron); op die horisontale vlerk-tot-vlerk-as hei (pitch) hy met die hoogteroer (elevator); en op die vertikale as gier (yaw) hy met die rigtingsroer (rudder).

wannadering, wentel en waas: In 'n kwaai dwarswind (crosswind) wat eers krimp (back) en dan ruim (veer) moet daar 'n paar keer om die lughawe gewentel (orbited) word. Ná enkele wannaderings (missed approaches) en 'n deurlooplanding (touch-and-go landing) laat die vlieënier die eindnaderingsgebooie (landing checks) loop om die vliegtuig uiteindelik met ' $n$ suksesvolle volle landing (full-stop landing) terug op moeder aarde op die laaiblad (apron) te kry.

Die terme en nuutskeppings wat tydens aanbiedings bespreek is, word in die Prolingua-termlys opgeneem.

\subsubsection{Standaardisering en harmonisering}

Die waarde van die terminologiese beginsels 'standaardisering' en 'harmonisering' is tydens 'n Prolingua-aanbieding bespreek (Alberts 2012). Vakspesialiste en terminoloë poog om ondubbelsinnige, bron- en doeltaalterme vir goed gedefinieerde begrippe te verskaf. Om dié doel te bereik, is dit noodsaaklik om die presiese betekenisse van terme te bepaal ten einde gebruikers in staat te stel om dit te verstaan en op 'n universeel aanvaarbare wyse te gebruik (Alberts en 
Mollema 2013). Begrippe wat behoorlik nagevors, verklaar, met brontaalterme benoem en van vertaalekwivalente in doeltale voorsien is, kan deur gereelde gebruik in die betrokke vakgebied en tersaaklike tale penetreer. Sulke terme word dan deur herhaalde gebruik gestandaardiseer. Standaardisasie is ' $n$ natuurlike proses en nie iets wat op 'n vak- en taalgemeenskap afgedwing kan word nie. Taalliggame kan byvoorbeeld nie hul gesag gebruik om terme te standaardiseer nie, hulle kan wel die terme beoordeel in terme van die woordvormings-, spel- en skryfbeginsels wat eie aan 'n betrokke taal is. As terme nie gedokumenteer en gebruik word nie, kan hulle nie in die vakgebied en taal penetreer en gestandaardiseer word nie. Terminologie wat nie gestandaardiseer is nie veroorsaak kommunikasieprobleme.

Deur die korrekte aanwending van gestandaardiseerde terminologie kan die wetenskaplike, ekonomiese en tegnologiese kommunikasievermoëns van 'n land se inwoners ontwikkel word. Hoewel terminologiese en terminografiese aktiwiteite nie altyd koste-effektief is nie, is dit steeds van historiese, kulturele, sosiale, funksionele, akademiese en wetenskaplike belang om soveel moontlik terminologieë te sistematiseer, te dokumenteer, te standaardiseer en te dissemineer (Alberts 2003: 128).

Die ander belangrike terminologiese beginsel wat ook bepreek is, is 'harmonisering' (Alberts 2012). In Suid-Afrika veroorsaak taalkontak dat die taalgebruikers van verskillende tale onderling by mekaar kan leer en leen en selfs, wanneer dit by termskepping kom, soortgelyke termekwivalente vir dieselfde konsep en brontaalterm (kan) skep. Hierdie termekwivalente se stam kom gewoonlik ooreen, maar die spel- en skryfwyse is aangepas by die betrokke taal se stelsel. Geharmoniseerde terme het ' $n$ beter kans om in verwante tale te penetreer en verminder die proliferasie van termekwivalente in verwante tale. Die fokus is hier op die versameling van brontaalterme en doeltaaltermekwivalente en die standaardisering daarvan deur middel van behoorlike definisies eerder as op die skep van nuwe terme in verwante tale. Dit is dus van belang om by die benoeming van nuwe begrippe (veral in die geval van nuutskeppings) die ander taalgemeenskappe te nader om te verneem of die begrip reeds benoem is. Die termekwivalent behoort dan volgens die woordvormings-, spelen skryfbeginsels van die betrokke taal oorgeneem te word. Voorbeelde van harmonisering in die SRTAT-databasis is:

bribe $v$ (en): omkoop (af); -reka (ns); -reka (tn)

trade $n$ (en): handel (af); kgwebo (ns, ss, tn); ukuhweba (zu)

law $n$ (en): wet (af); molao (ns, ss, tn); umthetho (xh, zu)

\section{Samewerking met ander instansies}

Prolingua en sy voorgangers het oor die afgelope 67 jaar daarin geslaag om ' $n$ goeie samewerkingsverhouding met verskeie instansies op te bou. Dit is simbiotiese verhoudings met wedersydse voordele vir die vereniging en die betrokke instansies. 


\subsection{Suid-Afrikaanse Vertalersinstituut}

Prolingua het 'n jarelange verbintenis met die Suid-Afrikaanse Vertalersinstituut (SAVI) wat inderwaarheid uit Prolingua se voorgangers voortgespruit het. Verskeie taalpraktisyns is dan ook lede van sowel Prolingua as SAVI en die lede van albei instansies word voortdurend op die hoogte gehou van hul onderskeie bedrywighede (Prolingua 2015: 5). Murato, SAVI se vaktydskrif, wat 'n verskeidenheid artikels oor taal en verwante kwessies en inligting oor instituutsake bevat, word ook onder Prolingua-lede versprei.

SAVI is by die Fédération Internationale des Traducteurs (FIT) (Internasionale Federasie van Vertalers) geaffilieer en het in samewerking met FIT dié instelling se veeltalige vertaalterminologielys in Afrikaans vertaal. Die vertaalterme is in 2010 gepubliseer met die titel Veeltalige vertaalterminologie/Multilingual Translation Terminology. Die uitdagings en struikelblokke wat by die vertaling van die FIT-vertaalterminologielys in Afrikaans ondervind is, is tydens 'n Prolingua-werksvergadering met die lede gedeel (Beukes en Pienaar 2011).

\subsection{Suid-Afrikaanse Akademie vir Wetenskap en Kuns}

Daar is goeie samewerking tussen Prolingua en die Suid-Afrikaanse Akademie vir Wetenskap en Kuns (SAAWK). Sommige Prolingua-lede is ook Akademielede. In 2010 is Prolingua se volledige boekery aan die SAAWK geskenk. Heelwat Prolingua-lede het ook vakwoordeboeke in hul privaat besit aan die SAAWK geskenk.

Buiten die skenkings wat van Prolingua en sy lede ontvang is, het die woordeboekargief by die SAAWK alreeds talle algemene woordeboeke in verskeie tale beskikbaar, soos Engels, Duits, Russies, Portugees, ens., onder andere in kombinasie met Afrikaans. Die SAAWK het ook 'n aansienlike aantal vakwoordeboeke in sy besit wat oor verskeie jare deur verskillende taalkantore en individue saamgestel is. Die terme in die vakwoordeboeke en termlyste is steeds baie bruikbaar, maar dit is nie altyd moontlik om die vakwoordeboeke of termlyste te bekom nie. Die meeste vakwoordeboeke is reeds uit druk en sommiges is nooit hersien nie. Die vakwoordeboeke sluit omtrent alle vakgebiede of navorsingsterreine in (Alberts 2015a). Daar is selfs 'n Deense vakwoordeboek oor elektronika en een oor boutegnologie — gelukkig in kombinasie met Engels en Duits. Die Deense terme lyk selfs na Afrikaanse skeppings en sou gebruik kon word om, waar nodig, Afrikaanse terme na aanleiding daarvan te skep. Daar is ook terminologielyste in die amptelike Afrikatale, byvoorbeeld die ou terminologie, ortografie- en spelreëls van die Afrikatale, die jongste spel-en skryfreëls wat deur die Nasionale Taalliggame van PanSAT in 2008 saamgestel is en ' $n$ lys met viertalige staatkunde en politieke terme.

Daar is egter geen sin daarin om 'n woordeboekargief te hê wat nie gedeel word nie. Die navorsingsmateriaal, algemene en vakwoordeboeke is gevolglik behoorlik aangewins en 'n vertrek word tans in die nuwe Akademie-gebou 
ingerig om die bronne toeganklik te maak.

Die Afrikaanse Woordelys en Spelreëls (AWS) van die Taalkommissie van die SAAWK word gereeld by Prolingua onder die loep geneem en lede word op die hoogte gehou van nuwe verwikkelinge op die terrein van die Afrikaanse spel- en skryfwyse (McLachlan 2011, 2012; Van Huyssteen en Kapp 2017).

\subsection{Die Virtuele Instituut vir Afrikaans}

Die SAAWK ondersteun die Virtuele Instituut vir Afrikaans (VivA) en gevolglik beskik die SAAWK oor 'n uitstekende infrastruktuur waarmee terminologiewerk gedoen kan word. VivA is 'n gesamentlike inisiatief van die SAAWK, die Dagbreek Trust, die Sentrum vir Tekstegnologie $\left(\mathrm{CTexT}^{\circledR}\right)$ van die Noordwes-Universiteit en die Afrikaanse Taal- en Kultuurvereniging (ATKV). Alle aspekte ten opsigte van die struktuur, grammatika, dokumentering en ontwikkeling van Afrikaans word reeds deur VivA ondervang, vgl. http://vivaafrikaans.org. VivA het ook toegang tot die vakwoordeboeke wat deur Prolingua gedigitiseer is.

VivA is op Afrikaans as digitale taal gerig. Die hoofdoel is om toegang tot terme en ander inligting oor en in Afrikaans te skep. Tydens 'n aanbieding by 'n Prolingua-werksvergadering (Van Huyssteen 2014) is voorgestel dat Prolingua by VivA betrokke kon raak deur saam te werk aan die skep van 'n termbank. Die lede het tydens die vergadering besluit om die aanbieding, VivA se sakeplan, asook inligting oor moontlike samewerking aan alle lede te stuur. Daarna is ' $n$ stemming per e-pos gehou sodat alle lede aan die besluitnemingsproses kon deelneem. Die lede het aangedui dat hulle graag by VivA betrokke sou wou wees, dat daar skakels tussen Prolingua en VivA se webwerwe moet wees en dat beide instansies daardeur wedersyds op die hoogte gehou kan word van aktiwiteite en data kan uitruil.

VivA het onlangs 'n Afrikaanse woordeboektoepassing (toep) bekend gestel wat met die ondersteuning van die Atterbury Trust ontwikkel is. Die gratis toep verleen kitstoegang tot sewe Afrikaanse woordeboeke en woordelyste (SAAWK 2015b: 7). Dié soort toepassing is beslis ook moontlik vir termlyste en vakwoordeboeke.

\section{$5.4 \quad$ CTexT}

Die Sentrum vir Tekstegnologie $\left(\mathrm{CTexT}^{\circledR}\right)$ op die Potchefstroomkampus van die Noordwes-Universiteit het die oopbron Autshumato Terminology Management System (TMS) ('n terminologiebestuurstelselprogram) ontwikkel en die VivAprojek gebruik die TMS om terme, gesegdes, vertalings, etimologie en taaladvies vas te lê. Hierdie inligting word onmiddellik beskikbaar gestel deur die webwerf (http://viva-afrikaans.org). Die gebruik van VivA se infrastruktuur maak dit moontlik om termbanke aan VivA te lisensieer. Daar word dan onder- 
ling bepaal of die terminologiese data gratis of teen betaling aan gebruikers beskikbaar gestel word.

In 2014 is Prolingua-lede aan die hand van 'n aanbieding en demonstrasies ingelig oor die Autshumato-vertaalprogram wat ook deur CTexT ontwikkel is (Fourie 2014). Die Autshumato-vertaalprogram is deur die Departement van Kuns en Kultuur geïnisieer tot voordeel van al die amptelike tale in SuidAfrika. Die doel daarmee is om vertaalwerk en die standaardisering van terme te vergemaklik.

\subsection{Tersiêre instansies}

Verskeie lede is verbonde aan die akademiese departemente en taaldienste van tersiêre instansies en hou hulle kollegas op die hoogte van Prolingua-bedrywighede, aanbiedings en publikasies. Kollegas word gevolglik ook na die aktiwiteite wat aangebied word, uitgenooi en selfs ook versoek om praatjies oor taalverwante sake by werksvergaderings, werksessies en die algemene jaarvergaderings aan te bied. Op hul beurt word die lede op die hoogte gehou van aktiwiteite wat by die kampusse van tersiêre instansies aangebied word, soos taaldebatte, slypskole, werksessies, kortkursusse en modules oor vertaling, tolking, terminologie, leksikografie en praktiese demonstrasies van rekenaartoepassings en -programmatuur wat die werk van taalpraktisyns kan vergemaklik. Lede word ook dikwels uitgenooi om aan navorsingsprojekte deel te neem, byvoorbeeld aanlyn vraelyste oor een of ander aspek van taal.

Die Departement van Hoër Onderwys het in 2013 fondse bewillig om ' $n$ veeltalige oopbrontermbank vir Hoër Onderwys tot stand te bring. Die oorhoofse doel van hierdie projek is die vestiging van 'n veeltalige termbank met oop toegang binne Hoër Onderwys. Op sy beurt het die termbank ten doel om terminologieontwikkeling tussen tersiêre instansies onderling te koördineer en om die amptelike Afrikatale (Afrikaans ingesluit) te ontwikkel as tale van akademiese diskoers - spesifiek om studente via hulle moedertale toegang te gee tot kernbegrippe in akademiese dissiplines (Alberts 2015a: 57). Die Prolinguawerksaamhede en -termlys sou ook hier tot sinvolle samewerking kan lei.

\subsection{Terminologiekoördineringsafdeling}

Die nasionale termbank wat deur die nasionale terminologiekantoor, die Terminologiekoördineringsafdeling (Terminology Coordination Section) van die Nasionale Taaldiens, Departement van Kuns en Kultuur bedryf word, stel terminologie aan alle landsburgers deur die Departement se webtuiste beskikbaar. Daar word hoofsaaklik terminologiewerk vir die verskillende staatsdepartemente gedoen en ander vakterreine en domeine kry nie meer soos vantevore aandag nie.

Terminologieontwikkeling dra by tot die ontwikkeling en bevordering 
van tale en is dus 'n direkte reaksie op die Grondwet van die Republiek van Suid-Afrika (1996) ten opsigte van die ontwikkeling van die amptelike tale. Meertalige terminologie is noodsaaklik om die tale tot funksionele tale met volle hoëvlakfunksies te laat ontwikkel. Engels word by die nasionale terminologiekantoor as brontaal aangewend en terme word slegs in Engels gedefinieer en van vertaalekwivalente in die ander tien amptelike tale voorsien.

Tans is daar net een terminoloog per taal by die nasionale terminologiekantoor werksaam. Nuutaangestelde terminoloë kry deesdae slegs indiensopleiding ten opsigte van die metodologie en hantering van die Autshumato TMS (terminologiebestuurstelselprogram). Dit blyk dat daar tans geen behoefte is aan opleiding wat verband hou met terminografiese beginsels en praktyk nie. Terminoloë wat egter nie in die teoretiese en praktiese begronding van terminologie as wetenskap en praktyk opgelei is nie, kan nie sinvolle terminologieontwikkeling bewerkstellig nie (Alberts 2015a).

In die verlede, tydens die voormalige tweetalige bestel, is tweetalige termlyste en vakwoordeboeke deur die voorgangers van die Terminologiekoördineringsafdeling saamgestel. Toe was dit die nasionale terminologiekantoor se hoofdoel om Afrikaanse terminologie te bevorder. Tans word Afrikaans bloot as een van die doeltale beskou en aangesien daar reeds Afrikaanse terme in verskeie vakgebiede gedokumenteer is, word geen daadwerklike poging aangewend om nuwe terme in dié taal te ontwikkel nie. Die terminoloë by die nasionale terminologiekantoor raadpleeg gevolglik dikwels die Prolinguatermlys wanneer Afrikaanse termekwivalente benodig word.

\subsection{Nasionale Leksikografiese Eenhede}

Die vereniging werk ook saam met die Nasionale Leksikografiese Eenhede (NLE's), soos die Buro van die Woordeboek van die Afrikaanse Taal (WAT) en die Dictionary of South African English (DSAE). Die twee NLE's hou Prolingua-lede op die hoogte van hul werksaamhede en die lede maak op hul beurt gebruik van die leksikografiese produkte van die NLE's.

Lede het in 2016 deelgeneem aan die Dictionary of South African English se aanlyn ondersoek om die aanlyn weergawe van die woordeboek te verbeter. Die sitate wat sedert die 17de eeu in die historiese Engelse woordeboek opgeneem is, bevat taal- en linguistiese data wat waardevol is vir taalpraktisyns. Die doel van die aanlyn vraelys was om hierdie Suid-Afrikaanse kulturele leksikografiese bron deur middel van die elektroniese medium meer dinamies, buigbaar en toeganklik te maak (DSAE 2016).

\subsection{Afrilex}

Prolingua het ' $n$ jarelange verbintenis met die African Association for Lexicography (Afrilex), 'n vakvereniging wat op leksikografie konsentreer en wat in 
1994 gestig is. Verskeie taalpraktisyns is dan ook lede van sowel Prolingua as Afrilex en die lede van albei instansies word voortdurend op die hoogte gehou van hul onderskeie bedrywighede. Prolingua-lede publiseer gereeld in Lexikos, Afrilex se vaktydskrif en woon gereeld Afrilex-konferensies en -seminare by en Afrilex-lede bied praatjies aan by Prolingua.

\subsection{Uitgewers}

Anders as in die geval van algemene woordeboeke, is 'n vakwoordeboek gewoonlik slegs bestem vir 'n klein spesialisgebruikersgroep en om vakwoordeboeke te publiseer is dus nie so ' $n$ betalende bedryf vir uitgewers nie (Hanekom 2012).

Om vakwoordeboeke en terminologielyste aanlyn beskikbaar te maak, sal steeds ' $n$ groot koste-implikasie hê. Die grootste uitgawe sal die omskakeling van papier- na elektroniese formaat wees van woordeboeke wat reeds uit druk is. Daar is uiteraard ook koste verbonde aan die bou van 'n webwerf en die instandhouding daarvan. Daar sal ook mannekrag- en koste-implikasies wees om woordeboeke en termlyste wat reeds elektronies beskikbaar is, in die geskikte elektroniese formaat te kry en gereeld met nuwer weergawes te vervang (Luther 2005; Van Huyssteen 2014).

Dit is sekerlik haalbaar, maar die vraag is egter of ander mediahuise en uitgewers by so 'n nasionale plan vir uitgewerye betrokke sal wil raak - dit gaan immers by elke mediahuis en uitgewer oor finansiële oorlewing in ' $n$ uiters mededingende bedryf. Dit sal egter in belang van vaktaalontwikkeling wees indien indringende onderhandelinge met mediahuise en uitgewers gevoer sou kon word om hulle te oortuig dat dit vir hulle sowel as vaktaalgebruikers van groot waarde kan wees as vaktaalprodukte (as drukkopieë en aanlyn) steeds gepubliseer kan word. Die Prolingua-termlys verskaf dus in ' $n$ groot mate terminologiese data wat andersins verlore sou wees.

\section{Die pad vorentoe}

'n Daadwerklike gesamentlike poging behoort deur Prolingua en al bogenoemde instansies aangewend te word om meertalige terminologie in ' $n$ verskeidenheid van dissiplines te ontwikkel, te dokumenteer en nasionaal beskikbaar te stel. Sonder vaktaal kan daar immers nie sprake wees van behoorlike vakkommunikasie nie. Die internasionale terminologienetwerk TermNet se leuse is: "There is no knowledge without terminology".

Verskeie (vak)taalkantore (by nasionale, provinsiale, munisipale en (semi)staatsinstellings, banke, ens.) versamel steeds terminologie vir interne gebruik. Die nasionale terminologiekantoor stel meertalige terminologielyste saam en hou 'n nasionale register by om terminologieprojekte te registreer om samewerking te bewerkstellig en duplisering te voorkom. Privaat instansies, verenigings soos 
Prolingua, sentra soos die Sentrum vir Politieke en Verwante Terminologie in Suider-Afrika (CEPTSA) en die Sentrum vir Regsterminologie in Afrikatale (SRTAT), VivA, tersiêre instansies, uitgewers en individue stel steeds vakwoordeboeke of termlyste saam (Alberts 2015a).

Bestaande infrastruktuur, soos taalkantore, termbanke en digitale platforms, en finansiering moet benut word eerder as om nuut ontwikkel of verkry te word. Alle terminologie wat beskikbaar is (selfs terminologieprodukte wat reeds uit druk is), behoort gedigitaliseer te word en gratis aanlyn (byvoorbeeld by die Terminologiekoördineringsafdeling/VivA/tersiêre instansies/Prolingua) beskikbaar te wees of daar behoort koppelvlakke en skakels te wees na alle vaktaalaktiwiteite (Alberts 2015b).

Data behoort gedigitaliseer en oop te wees vir vrye toegang en algemene gebruik, want data wat nie oop gelisensieer is nie, raak onbruikbaar. Die terme wat aanlyn in die oop domein beskikbaar gestel word, moet van 'n hoë gehalte wees en die doeltreffendheid daarvan moet gereeld gemeet word. Daar behoort ook stelsels te wees vir kommentaar op vaktaaldata en wat die hersiening en bywerking daarvan sal vergemaklik

Dit sou geen doel dien om terminologie by Prolingua in isolasie te ontwikkel en vir eie gebruik te benut nie. Prolingua sou egter sy bestaande infrastruktuur, hulpbronne en bates kon aanwend om 'n enorme bydrae te lewer tot vaktaalontwikkeling, met spesiale klem op Afrikaanse vaktaal. Dit gaan myns insiens hier oor die volgende hulpbronne en bates:

- Vak- en taalkennis: Prolingua beskik oor lede wat 'n magdom vak- en taalkennis in pag het - baie Prolingua-lede is reeds afgetree, maar ander is nog aktief in bepaalde vakdissiplines en tale werksaam - en hierdie kundigheid (ook van die afgetredenes) behoort benut te word.

- Vakwoordeboeke: Prolingua-lede beskik oor 'n groot versameling vakwoordeboeke en termlyste vir eie gebruik. Die Prolingua-vakwoordeboekversameling is aan die SAAWK se boekery beskikbaar gestel vir navorsingsdoeleindes. Dié vakwoordeboeke is egter tot 'n baie groot mate ontoeganklik, aangesien die boekery fisies in Pretoria geleë is. Boonop is die meeste van dié vakwoordeboeke nie digitaal beskikbaar nie, wat ook 'n risiko met betrekking tot veiligheid en volhoubaarheid inhou. Daarenteen is die Prolingua-termlys aanlyn beskikbaar.

Vervolgens word konkrete aanbevelings gemaak hoe elk van hierdie bates ten beste benut kan word.

Vak- en taalkennis

- Prolingua-lede se kundigheid behoort nasionaal benut te word.

- Die Prolingua-lys is aanlyn beskikbaar op die Prolingua-webwerf en met behulp van skakels/koppelvlakke aan ander stelsels verbind. Die spesifieke doel daarmee is om kommentaar van ander vaktaalgebruikers op terminologiese data te ontvang en self kommentaar te lewer. 
- Deel kundigheid deur die vaktaaldata ook aan die nasionale termbank by die Terminologiekoördineringsafdeling, Nasionale Taaldiens, Departement van Kuns en Kultuur beskikbaar te stel sodat Afrikataalekwivalente bygevoeg kan word.

\section{Vakwoordeboeke}

- Gaan voort om vakwoordeboeke en termlyste te digitiseer wat nog nie in die Prolingua-lys opgeneem is nie. Die digitisering moet sover moontlik deur middel van skandering en optiese karakterherkenning geskied.

- Noue skakeling met veral VivA is noodsaaklik om duplisering te verhoed.

- VivA kan gedigitiseerde data digitaliseer.

- Die gedigitaliseerde Prolingua-termlys kan op sowel Prolingua as VivA se webwerwe beskikbaar gestel word, met 'n aanduiding daarby dat Prolingua oor die outeursreg beskik.

Voordele verbonde aan die benutting van VivA se infrastruktuur is die volgende:

- Eenstopdiens: (Vak)taalgebruikers sal 'n eenstopdiens by VivA kan hê. Skakels kan (vak)taalgebruikers met Prolingua en ander bronne verbind.

- Navraagdiens: Terminologiese navrae kan deur VivA se taaladviesdiens gekanaliseer word. Die taaladviseur kan met behulp van bestaande terminologiebanke by VivA termnavrae beantwoord. Prolingua sou ook ' $n$ lys van kundiges, wat bereid sou wees om die taaladviseur by te staan, aan VivA beskikbaar kon stel. Daar sou selfs 'n skakel kon wees na die Prolingua-geselsgroep (Prolingua99@yahoo.com).

- Tegnologie en infrastruktuur: Die nodige tegnologie en infrastruktuur bestaan reeds by VivA. Prolingua het dus nie nodig om enige platforms te onderhou of nuwe tegnologie te ontwikkel nie - dit word reeds deur VivA gedoen.

- Termbank(e): VivA se programmatuur en platforms maak daarvoor voorsiening dat data uit verskillende bronne benut kan word. Die data word met behulp van bestaande koppelvlakke met VivA se stelsel versoen en indien nodig kan 'n doelgemaakte koppelvlak ontwikkel word om nuwe projekte se terminologiese data met die stelsel te versoen. Nuwe projekte kan bloot by die bestaande stelsel gevoeg word sodra die data toeganklik gemaak is en aanlyn beskikbaar gestel word. VivA-terminologie kan ook aan die Afrikatale beskikbaar gestel word vir die byvoeging van die ander amptelike Suid-Afrikaanse tale

- Beskikbaarstelling (gratis): Die terminologiese data kan gratis op VivA se webwerf en mobiele toepassing ("toep") beskikbaar gestel word. Dit pas in by VivA se sakemodel om soveel as moontlik inligting gratis beskikbaar te stel. (Dit voorkom ook dat nog geld op tegnologie spandeer word, terwyl dit eintlik aan inhoud spandeer kan word.)

- Beskikbaarstelling (betaald): VivA se webwerf beskik ook oor die moontlikheid om sommige woordeboekinhoud teen betaling beskikbaar te stel. 
Dit gaan egter spesifiek oor kommersiële woordeboeke (byvoorbeeld algemene woordeboeke soos die WAT en HAT en gepubliseerde vakwoordeboeke, byvoorbeeld deur uitgewers soos Juta en Pharos). In sulke gevalle kan gebruikers deur die webwinkel toegang tot die data bekom; tantieme $(70 \%)$ word aan woordeboekverskaffers (byvoorbeeld Prolingua) betaal, want die lisensiehouer kry telkens betaling wanneer sy data deur middel van VivA benut word. Die aanbeveling hier is egter dat Prolingua soveel as moontlik van sy vakwoordeboekdata gratis deur middel van VivA aan gebruikers beskikbaar moet stel.

- Kundigheid: VivA het reeds 'n model daargestel om vak-, taal- en tegnologiese kundigheid te verenig. CTexT van die Noordwes-Universiteit verskaf die tegnologiese kundigheid wat ook in die artikel bespreek word en Prolingua sou dus kon bydra deur taal- en vakkundigheid hiertoe toe te voeg.

- Opleiding: Teoretiese vakleksikografiese opleiding sou aanlyn by VivA se webseminare (webinare) aangebied kon word.

\section{Samevatting}

Taalpraktisyns het daagliks terminologie nodig vir die werksaamhede verbonde aan hul beroepe. Afrikaanse terme is klaarblyklik steeds nodig en waar dit nie aktief deur ander instansies ontwikkel word nie, het Prolingua en sy voorgangers getoon dat die instansie doelbewus poog om 'n nasionale terminologiediens te lewer en daardeur sorg te dra dat die ontwikkeling van veral Afrikaanse vaktaal nie agterweë bly nie. Prolingua kan deur sy eie inisiatiewe Afrikaanse terme volhoubaar ontwikkel, bewaar en dissemineer. Prolingua kan ook deur samewerking met ander instansies aktief betrokke wees by die voortdurende en volhoubare ontwikkeling van die amptelike tale as gebruiks- en wetenskapstale wat vir alle doelgebruikers van waarde kan wees.

Dit sou interessant wees om te sien in welke mate geïsoleerde terminologieontwikkeling, soortgelyk aan dié vir Afrikaans deur Prolingua, in die ander amptelike tale deur enkele instansies onderneem word.

\section{Bibliografie}

Alberts, M. 1998. Vaktaalontwikkeling in Suid-Afrika. Referaat gelewer by LVSA-kongres, 1 Julie 1998, Potchefstroom.

Alberts, M. 2000a. Audit on South African Terminology Projects. Julie 2000. Ongepubliseerde dokument. Pretoria: Nasionale Terminologiediens, Departement van Kuns, Kultuur, Wetenskap en Tegnologie.

Alberts, M. 2000b. Terminology Management at the National Language Service. Lexikos 10: 234-251.

Alberts, M. 2003. Vaktaalontwikkeling en -opleiding in Suid-Afrika. Botha, Willem (Red.). 2003. ' $n$ Man wat beur. Huldigingsbundel vir Dirk van Schalkwyk: 127-161. Stellenbosch: Buro van die WAT. 
Alberts, M. 2012. Sentrum vir Regsterminologie in Afrikatale (SRTAT) - ' $n$ Oorsig van die projek oor straf-, strafproses- en bewysreg. Referaat gelewer by die Prolingua-werksvergadering, 10 Julie 2012, Unisa, Florida-kampus, Roodepoort.

Alberts, M. 2015a. ' $n$ Oorsig van vaktaalontwikkeling en -opleiding in Suid-Afrika met spesiale verwysing na Afrikaans. Ongepubliseerde verslag opgestel in opdrag van Die Dagbreek Trust en die Suid-Afrikaanse Akademie vir Wetenskap en Kuns, November 2015.

Alberts, M. 2015b. Die Akademie se Vaktaalburo - verlede, hede en toekoms. Ongepubliseerde verslag opgestel in opdrag van Die Dagbreek Trust en die Suid-Afrikaanse Akademie vir Wetenskap en Kuns, Desember 2015.

Alberts, M. 2017. Terminology and Terminography Principles and Practice. A South African Perspective. Milnerton: McGillivray Linnegar (MLA Publications).

Alberts, M. en N. Mollema. 2013. Developing Legal Terminology in African Languages as an Aid to the Court Interpreter: A South African Perspective. Lexikos 23: 29-58.

Beukes, S.M. 2014. SA Language Practitioners' Council Bill. Referaat gelewer by die Prolinguawerksvergadering, 13 Mei 2014, Unisa, Florida-kampus, Roodepoort.

Beukes, S.M. en M. Pienaar. 2011. Uitdagings en struikelblokke by die vertaling van die FIT-vertaalterminologielys in Afrikaans. Referaat gelewer by die Prolingua-werksvergadering, 8 Maart 2011, Unisa, Florida-kampus, Roodepoort.

Bosman, J.P. 2015. Ons Griekse-Latynse erfenis/Our Latin Greek Heritage. Ons dink, praat en skryf daagliks in Grieks en Latyn en ons besef dit nie: ' $n$ Vertrekpunt vanuit die mediese taal. Referaat gelewer by die Prolingua-werksvergadering, 10 Junie 2015, Tshwane Munisipaliteit, Centurion.

Botha, S., P. le Clus en A.J. Venter (Reds.). 2011. Modern Political Dictionary/Nuwerwetse Politieke Woordeboek. CEPTSA. Auckland Park: Universiteit van Johannesburg.

Burger, C. 2016. Radiotegnologie en radioterme. Referaat gelewer by die Prolingua-werksvergadering, 12 Oktober 2016, Tshwane Munisipaliteit, Centurion.

Burger, P. en J. de Jong. 1997. Handboek Stijl: Adviezen voor aantrekkelijk schrijven. Groningen: Martinus Nijhoff.

Buys, F. 2014. Afrikaanse universiteit bekendgestel. Pretoria East Rekord, November 2014: 4.

Carstens, W.A.M. 2011. Teksredaksie (2010). Referaat gelewer by die Prolingua-werksvergadering, 10 Mei 2011, Unisa, Florida-kampus, Roodepoort.

Carstens, W.A.M. 2014. Die storie van Afrikaans: Uit Europa en van Afrika. 'n Biografie van Afrikaans. Referaat gelewer by die Prolingua-werksvergadering, 8 Oktober 2014, Tshwane Munisipaliteit, Centurion.

Carstens, W.A.M. en K. van de Poel. 2010. Teksredaksie. Stellenbosch: SUN Media.

CLTAL (Centre for Legal Terminology in African Languages). 2015. Legal Terminology: Criminal Law, Procedure and Evidence/Regsterminologie: Straf-, Strafproses- en Bewysreg. Kaapstad: Juta.

Combrink, A. 2015. Moets, moenies en hoekoms: Taalversorging van akademiese geskrifte. Werksessie, 10 Maart 2015, Unisa, Florida-kampus, Roodepoort.

Cornelius, E. 2012. ' $n$ Verkenning van die leksikogrammatikale kompleksiteit van regstaal en die vereenvoudiging daarvan. Referaat gelewer by die Prolingua-werksvergadering, 10 April 2012, Tshwane Munisipaliteit, Centurion.

Dorfling, J. 2002-2011. Brugwoordeboek. www.prolingua.org.za.

Dorfling, J. 2012. Brugterme en die Brugakademie in Pretoria. Referaat gelewer by die Prolinguawerksvergadering, 12 Junie 2012, Tshwane Munisipaliteit, Centurion. 
DSAE. 2016. DSAE Reader Survey. (www.dsae.co.za; http://dsae.limequery.com/index.php/ survey/). April 2016.

Du Plessis, M. 2016. Storietyd! Terme en begrippe in die letterkunde. Referaat gelewer by die Prolingua-werksvergadering, 10 Februarie 2016, Tshwane Munisipaliteit, Centurion.

Dykman, D.J. 2012. When You Use those Words, Don't Abuse, Confuse or Misuse those Words. Werkwinkel oor die korrekte gebruik van Engelse woorde aangebied by die Universiteit van Johannesburg, 11 September 2012, Auckland Park.

Dykman, D.J. 2013. When You Use those Words, Don't Abuse, Confuse or Misuse those Words. Referaat gelewer by die Prolingua-werksvergadering, 9 Oktober 2013, Tshwane Munisipaliteit, Centurion.

Dykman, D.J. 2015. Powerful Presentations: Guidelines on Effective Speaking. Werksessie oor die gebruik van Engels aangebied by die Prolingua-werksvergadering, 14 Oktober 2015, Tshwane Munisipaliteit, Centurion.

Dykman, D.J, J.D.U. Geldenhuys en E.E. Viljoen-Smook. 2014. The Write Stuff: The Style Guide with a Difference. Derde uitgawe. Kaapstad: NB-Uitgewers.

Fourie, W. 2014. Autshumato-projek. Referaat gelewer na afloop van Prolingua se Algemene Jaarvergadering, 10 Augustus 2014, Tshwane Munisipaliteit, Centurion.

Geldenhuys, J.D.U. en E.E. Viljoen-Smook. 2009. Business Dictionary/Sakewoordeboek. Vyfde hersiene uitgawe. (www.pharosonline.co.za). Kaapstad: Pharos.

Geldenhuys, J.D.U, D.K. Dykman en B. Viljoen-Smook. 2012. Saketaal, die jongste Sakewoordeboek en 'The Write Stuff'. 'n Vraag-en-antwoordsessie aangebied by die Prolingua-werksvergadering, 8 Mei 2012, Unisa, Florida-kampus, Roodepoort.

Hanekom, D. 2012. Die uitgewersbedryf en die publikasie van boeke. Referaat gelewer by die Prolinguawerksvergadering, 14 Februarie 2012, Tshwane Munisipaliteit, Centurion.

Human, D. 2016. Uitdagings om die Bybel beter te verstaan. Referaat gelewer na afloop van Prolingua se Algemene Jaarvergadering, 10 Augustus 2016, Tshwane Munisipaliteit, Centurion.

Jonker, T. 2013. Sweeftuie en sweeftuigterme. Referaat gelewer by die Prolingua-werksvergadering, D-Ring 353, Universiteit van Johannesburg, Aucklandpark-kampus.

Kotzé, E.F. 2015. Die aard en werkswyse van die Forensiese Linguistiek. Referaat gelewer na afloop van Prolingua se Algemene Jaarvergadering gehou op 12 Augustus 2015 by die Kunsgalery, Voortrekkermonument, Pretoria.

Le Roux, W. 2016. Benamings van die land se howe. Taalwys, 7 Junie 2016.

Liebenberg, W., M. Delport en E. Greenfield. 2016. WordFast Classic Workshop. 'n Inleiding tot WordFast Classic aangebied op 23-25 Mei 2016, Rigellaan, Pretoria.

Linnegar, J.D. 2013. CCC: An Inclusive New Model for Ensuring that Text Editors Intervene in Texts Systematically. Referaat gelewer by die Prolingua-werksvergadering, 12 Junie 2013: Tshwane Munisipaliteit, Centurion.

Linnegar, J.D. 2014. CCC: An Inclusive New Model for Ensuring that Text Editors Intervene in Texts Systematically. Miniwerkwinkel aangebied by die Prolingua-werksvergadering, 9 September 2014, Unisa, Florida-kampus, Roodepoort.

Luther, Jana. 2005. Vaktaalontwikkeling. Ongepubliseerde artikel.

Malan, K. 2014. Amptelike tale as tale vir die notulering van hofverrigtinge. Referaat gelewer by die Prolingua-werksvergadering, 11 Junie 2014, Tshwane Munisipaliteit, Centurion.

Malete, N.E. 2016. Metheo ya ditokiso tsa sengolwa. Milnerton: McGillivray Linnegar (MLA Publications). 
Maree, K. 2014. Social Media: Our Changed Reality. Referaat gelewer by die Prolingua-werksvergadering, 12 Februarie 2014, Tshwane Munisipaliteit, Centurion.

McLachlan, J.D. 2011.Taalgebruik. 'n Taalgebruiksessie aangebied na afloop van Prolingua se Algemene Jaarvergadering, 2 Augustus 2011, Tshwane Munisipaliteit, Centurion.

McLachlan, J.D. 2012. Taalnavrae. 'n Taalgebruiksessie aangebied na afloop van Prolingua se Algemene Jaarvergadering, 14 Augustus 2012, Tshwane Munisipaliteit, Centurion.

Mollema, N. en M. Alberts. 2011. Terminological Research: A Practical Guide for Court Interpreters. Referaat gelewer by die Departement van Justisie se konferensie: The Value and Professionalism of the Court Interpreter, 14-15 Oktober 2011, Universiteit van die Vrystaat, Bloemfontein.

Mtintsilana, P.N. en R. Morris. 1988. Terminography in African Languages in South Africa. South African Journal of African Languages 8(4): 109-113.

Nasionale Terminologiediens. 1998. Katalogus van vakwoordeboeke/Catalogue of Technical Dictionaries. (NTD 1998.) Pretoria: Departement van Kuns, Kultuur, Wetenskap en Tegnologie.

Posthumus, L. 2016. Deiksis en taal: Deiksis en die relevansie daarvan vir kommunikasie en vertaling. Referaat gelewer by die Prolingua-werksvergadering van 8 Maart 2016, Unisa, Florida-kampus, Roodepoort.

Prinsloo, D.J. 2011. Tekstegnologie - Die versameling, analise, manipulering en markering van teks. Referaat gelewer by die Prolingua-werksvergadering, 11 Oktober 2011, Tshwane Munisipaliteit, Centurion.

Prolingua. 2015. Prolingua 65! 'n Vereniging vir Afrikaanse en Engelse Taalpraktisyns. An Association for English and Afrikaans Language Practitioners. 28 Oktober 1950-12 Augustus 2015. Pamflet saamgestel ter viering van Prolingua se 65ste bestaansjaar.

Prolingua. 2016. Notule van 'n werksvergadering van Prolingua gehou op Dinsdag, 13 September 2016, Florida-kampus van Unisa, Roodepoort.

Prolingua. 2017a. Notule van 'n werksvergadering van Prolingua gehou op Woensdag 12 April 2017, Tshwane Munisipaliteit, Centurion.

Prolingua. 2017b. Items vir Bespreking (IvB). Werksvergadering 9 Mei 2017, Tshwane Munisipaliteit, Centurion.

Roux, J.C. 2016. Spraakbronne met onder meer leksikografie, terminologie en vertaling. Referaat gelewer by die Prolingua-werksvergadering, 12 Oktober 2016, Centurion. Tshwane Munisipaliteit, Centurion.

Russouw, J. 2017. Sport in Afrikaans oor die radio. Referaat gelewer by die Prolingua-werksvergadering, 8 Februarie 2017, Tshwane Munisipaliteit, Centurion.

SAAWK. 2015a. Notule van die Verkennende Gesprek oor Terminologie-ontwikkeling. 28 Augustus 2015. SAOU Raadsaal, Serenestraat 278, Garsfontein.

SAAWK. 2015b. Nuusbrief 53(2). Augustus 2015. www.akademie.co.za.

Sentrum vir Regsterminologie in Afrikatale (SRTAT). 2017. SRTAT-databasis: Regsterminologie: Straf-, Strafproses- en Bewysreg. SRTAT: Pretoria.

Van de Poel, K., W.A.M. Carstens en J.D. Linnegar. 2012. Text Editing: A Handbook for Students and Practitioners. Antwerpen, België: Antwerpen Universiteitsdrukkers.

Van Huyssteen, G.B. 2014. VivA! Die Virtuele Instituut vir Afrikaans. Referaat gelewer by die Prolingua-werksvergadering, 9 April 2014, Tshwane Munisipaliteit, Centurion.

Van Huyssteen, G.B. 2017. Lugvaartterme. Beskikbaar gestel uit die rubriek in die Beeld oor Lugvaartterme. E-pos gestuur op 2017-03-06. 
Van Huyssteen, G.B. en S. Kapp. 2017. Die nuwe Afrikaanse woordelys en spelreëls (2017). Referaat gelewer by die Prolingua-werksvergadering, 11 Oktober 2017, Tshwane Munisipaliteit, Centurion.

Van Nierop, L. 2016. Wat is in 'n naam? Die betekenis van slottitels in rolprente. Referaat gelewer by die Prolingua-werksvergadering van 10 Mei 2016, Unisa, Florida-kampus, Roodepoort.

Van Rooy, B. 2017. The Distinction between Innovation and Integration of New Expressions in a Language. Die onderskeid tussen innovasie en inburgering van nuwe uitdrukkings in 'n taal. Referaat gelewer by die Prolingua-werksvergadering, 9 Mei 2017. Unisa, Florida-kampus, Roodepoort.

Vereniging van Regslui vir Afrikaans (VRA). 2017. Landdroshowe se boek oor reëls in Afrikaans. Vertaling deur McLachlan, J.D. Pretoria: Maroela Media.

Viljoen-Smook, E.E., J.D.U. Geldenhuys en W. Coetzee. 2017. Business Writing for South Africans. Kaapstad: NB Uitgewers.

Von Solms, B. 2013. Die Kuberruimte - Die moderne Wilde Weste? Referaat gelewer by die Prolingua-werksessie, Dinsdag, 14 Mei 2013, D-Ring 353, Universiteit van Johannesburg, Aucklandpark-kampus.

Vos, C. 2015. Die literêre vertaling van die Ilias (Homerus) van Grieks na Afrikaans. Referaat gelewer by die Prolingua-werksvergadering, 8 April 2015, Tshwane Munisipaliteit, Centurion.

\section{Wetgewing}

\section{SA Grondwet:}

Constitution of the Republic of South Africa, 1996. (Act No. 108 of 1996.) (Nou: Constitution, 1996.)/ Grondwet van die Republiek van Suid-Afrika, 1996. (Wet 108 van 1996.) (Nou: Grondwet, 1996.)

\section{Outeursreg/Kopiereg:}

Copyright Act 98 of 1978/Kopieregwet 98 van 1978.

Copyright Amendment Act 9 of 2002/Kopieregwysigingswet 9 van 2002.

\section{Nasionale Taalbeleid en Implementeringsplan:}

National Language Policy Framework. Final Draft (NLPF)/Nasionale Taalbeleidsraamwerk. Finale Konsep. 13 November 2002. Pretoria: Departement van Kuns en Kultuur.

National Language Policy Framework (NLPF) and Implementation Plan/Nasionale Taalbeleidsraamwerk en Implementeringsplan. 2003. Pretoria: Departement van Kuns en Kultuur (DKK).

\section{Provinsiale Taalbeleidsraamwerk:}

Language Policy Framework of the Gauteng Provincial Government/Taalbeleidsraamwerk van die Gautengse Provinsiale Regering. 2005. Johannesburg: Gautengse Provinsiale Regering, Departement van Sport, Ontspanning, Kuns en Kultuur.

\section{SA Taalpraktisynsraad:}

South African Language Practitioners' Council Act 8 of 2014/Suid-Afrikaanse Taalpraktisynsraad Wet 8 van 2014.

\section{Gebruik van Amptelike Tale:}

Use of Official Languages Act 12 of 2012/Wet op die Gebruik van die Amptelike Tale, Wet 12 van 2012. Staatskoerant No. 35742, 2 Oktober 2012. Kaapstad: Staatsdrukker.

Use of Official Languages Act - Proposed Regulations/Wet op die Gebruik van die Amptelike Tale — Voorgestelde Regulasies. Staatskoerant No. 36392, Staatskennisgewing 411 van 2013, 26 April 2013: 56-67. Kaapstad: Staatsdrukker. 